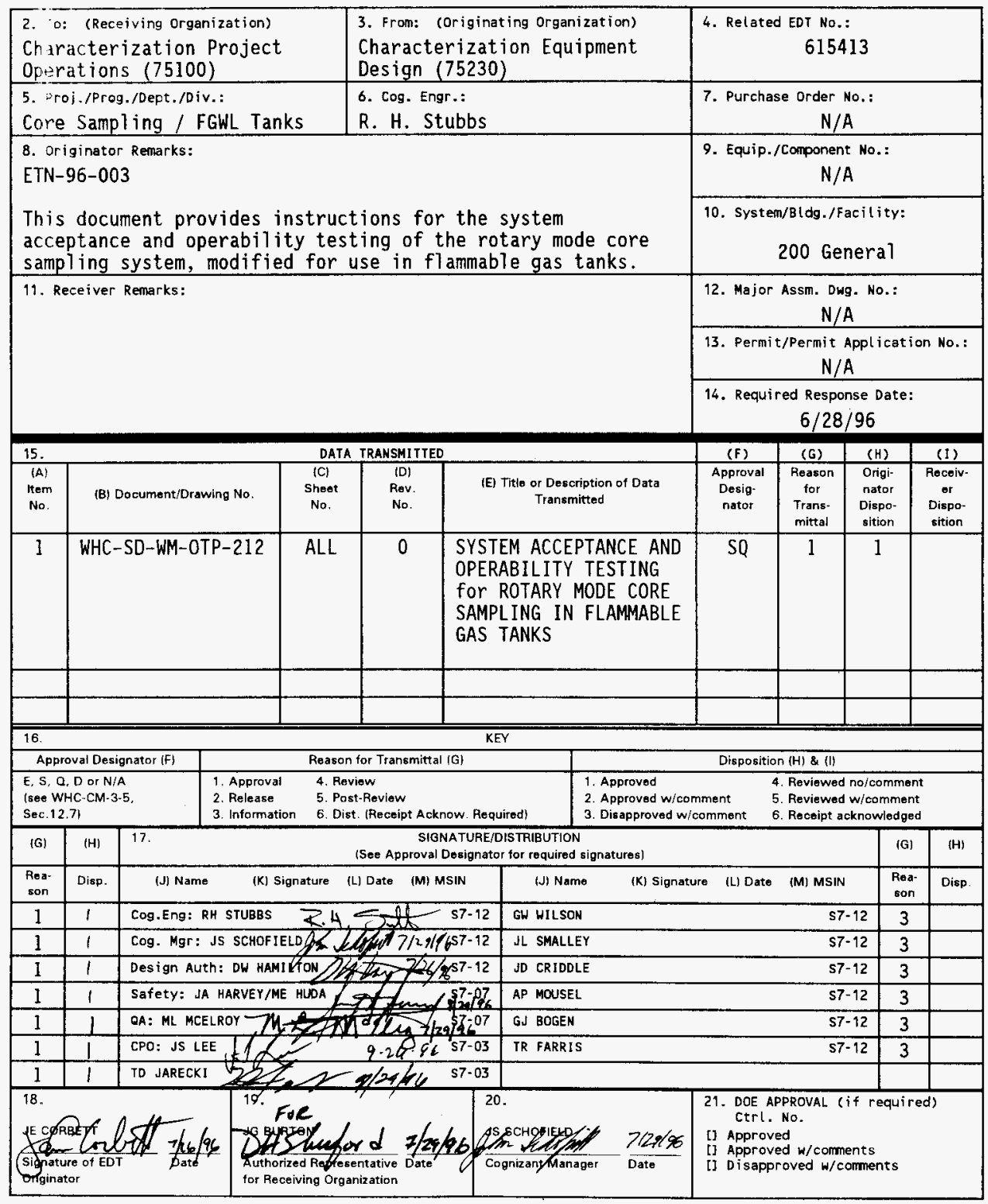




\title{
SYSTEM ACCEPTANCE AND OPERABILITY TESTING for ROTARY MODE CORE SAMPLING IN FLAMMABLE GAS TANKS
}

J. E. Corbett

Westinghouse Hanford Company, Richland, WA 99352

U.S. Department of Energy Contract DE-AC06-87RL10930

\author{
EDT/ECN: $618000 \quad$ UC: 2070 \\ Org Code: W75230 Charge Code: N4HBB \\ B\&R Code: Fwz20074 Total Pages: 52
}

Key Words: RMCS, RMCST modifications, Core Sampling, Flammable Gas Watch List Tank, Rotary Mode Core Sampling, RMCS, Core Sample Truck, Acceptance Testing, Operability Testing, ATP, OTP.

Abstract: This document provides instructions for the system acceptance and operability testing of the rotary mode core sampling system, modified for use in flammable gas tanks.

TRADEMARK DISCLAIMER. Reference herein to any specific commercial product, process, or service by trade name, tradenark, manufacturer, or otherwise, does not necessarily constitute or imply its endorsement, recommendation, or favoring by the United States Government or any agency thereof or its contractors or subcontractors.

Printed in the United States of America. To obtain copies of this document, contact: HHC/8CS Document Control Services, P.O. Box 1970, Mailstop H6-08, Richland WA 99352, Phone (509) 372-2420; Fax (509) 376-4989.
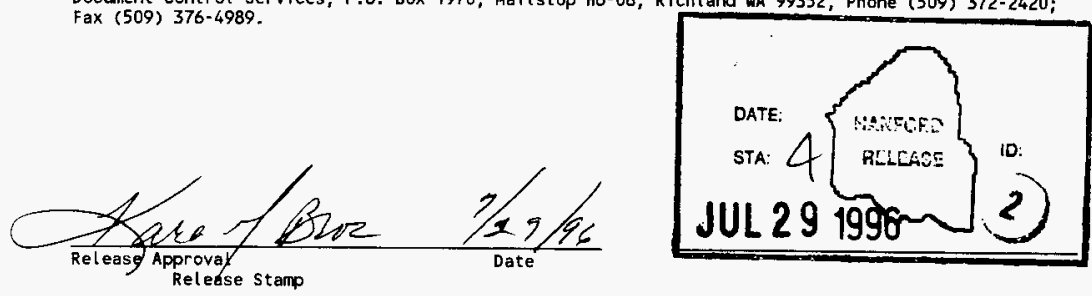

Approved for Public Release 
WHC-SD-WM-OTP-212 Rev. 0

SYSTEM ACCEPTANCE AND OPERABILITY TESTING

for

ROTARY MODE CORE SAMPLING

IN FLAMMABLE GAS TANKS

J. E. Corbett

TWRS Characterization Project

WESTINGHOUSE HANFORD COMPANY

JULY, 1996 


\section{TABLE OF CONTENTS}

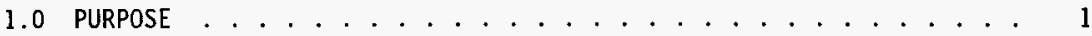

$2.0 \mathrm{SCOPE} \ldots \ldots \ldots \ldots \ldots \ldots$

3.0 RESPONSIBILITIES . . . . . . . . . . . . . . . . 2

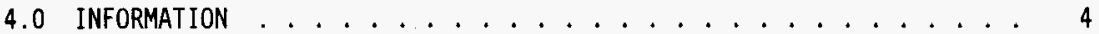

4.1 TERMS AND DEFINITIONS . . . . . . . . . . . . . . . 4

4.2 TEST GUIDANCE . . . . . . . . . . . . . . . . . . 4

4.3 REFERENCES . . . . . . . . . . . . . . . . . . . 6

4.4 SAFETY ISSUES . . . . . . . . . . . . . . . . 6

4.5 RADIATION AND CONTAMINATION CONTROL . . . . . . . . . 7

4.6 QUALITY ASSURANCE . . . . . . . . . . . . . . . . 7

4.7 SYSTEM ALARM ACTIVATION AND CANCELLATION . . . . . . . 7

4.8 ACCEPTANCE CRITERIA . . . . . . . . . . . . . . . 8

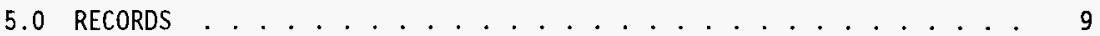

6.0 PREREQUISITES . . . . . . . . . . . . . . . . . . . 10

6.1 EQUIPMENT AND SUPPLIES . . . . . . . . . . . . . . . . . . . . 10

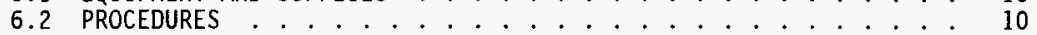

6.3 CONDITIONS . . . . . . . . . . . . . . . . . . . . 11

7.0 TEST PROCEDURE (EQUIPMENT) . . . . . . . . . . . . . . . 12

7.1 EQUIPMENT IDENTIFICATION AND SET UP . . . . . . . . . . . 12

7.2 CORE SAMPLE TRUCK START UP ..................... 15

7.3 DRILL RIG MANEUVERING . . . . . . . . . . . . . . 16

7.4 SAMPLE ACTUATOR / HBD (HYDRAULIC BOTTOM DETECTOR) . . . . . . . 18

7.5 SHIELOED RECEIVER / REMOTE LATCH UNIT . . . . . . . . . . . 21

7.6 NITROGEN SUPPLY SYSTEM . . . . . . . . . . . . . . . . . 23

7.7 CRITICAL ALARM CHECKS . . . . . . . . . . . . . . 27

7.8 SYSTEM START UP / POWER LOADING TEST . . . . . . . . . . 37

7.9 EXHAUSTER SHUTDOWN TESTS . . . . . . . . . . . . . 39

7.10 DRILL STRING LOCKING COLLAR / RISER SLEEVE SPRAY WASHER
TESTING . . . . . . . . . . . . . . . . .

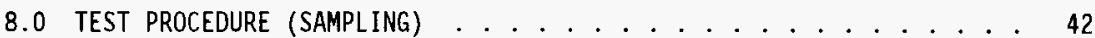

8.1 PREPARE TO SAMPLE . . . . . . . . . . . . . . . . . 42

8.2 PERFORM CORE SAMPLING . . . . . . . . . . 42

8.3 RECOVER SPENT SAMPLER FROM DRILL STRING . . . . . . . . . . . 43

8.4 INSERT EMPTY SAMPLER INTO DRILL STRING $\ldots . . . . . . . . .443$

8.5 RECOVER DRILL STRING AND SECURE EQUIPMENT $\ldots . . . . . . .43$

9.0 SIGNATURE LOG . . . . . . . . . . . . . . . . . . . 44

10.0 TEST COMPLETION SIGN-OFF . . . . . . . . . . . . . . 45

APPENDIXES: EXCEPTION / RESOLUTION DATA SHEET . . . . . . . . Al

TEST LOG COMMENT SHEET . . . . . . . . . . . . . . . . A2

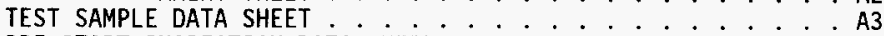

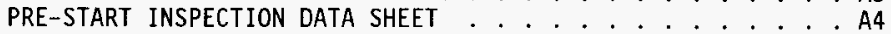




\subsection{PURPOSE}

The purpose of this system acceptance and operability test procedure is to provide instructions for system acceptance and operability testing of the rotary mode core sampling (RMCS) system modified for use on flammable gas tanks. This testing fulfills the applicable requirements of WHC-SD-WM-ETP-177, Section 3.2.7; WHC-SD-WM-FDC-048, Section 5.9; WHC-SD-WM-TP-488; WHC-SD-WM-SAD-035, chapter 6; and WHC-CM-6-1, EP-4.2 (see section 4.3 of this document for complete references).

\subsection{SCOPE}

System acceptance and operability testing of the Rotary Mode Core Sampling System will verify that system design requirements, as well as functional and operational requirements, have been met. Testing will be completed in two phases. The first phase of testing (section 7) will involve integrating and operating RMCS equipment to demonstrate acceptable operation of systems modified to perform tasks required during sampling of flammable gas tanks. The second phase of testing (section 8 ) will demonstrate the operational functioning by taking repeated samples in a simulated operational environment. These tests will be conducted at the "Rock Slinger" test site, located just south of U-Plant in the 200 West Area.

Tests will be done in a simulated flammable gas tank environment. All testing will be controlled to prevent contamination release, and stand-in materials shall be used to simulate waste tank conditions. To reduce hazardous waste generated during testing, sampler ball valves will be closed during sampling (no sample will be taken), and samplers may be reused in testing. Systems will interface in a manner similar to that expected in the field. 


\subsection{RESPONSIBILITIES}

Safety, QA, Characterization Project Operations (CPO), Equipment Design (CED), and Field Engineering (CFE) shall approve this test procedure (hereafter referred to as the OTP), prior to its release. Responsibilities are as follows :

\section{Operations Test Director}

Responsible for the overall performance of the 0TP. Responsible for the proper conduct of operations for the entire test site as well as all personnel involved in the testing. Ensures the execution of all testing activities are within the scope of the OTP. Exercises stop work authority for unsafe activities or activities not conforming to this OTP. Directs the overall conduct and sequencing of testing activities. Ensures configuration management is properly maintained. Directs actions to be taken to prevent injury to employees or damage to equipment. Acts through the core sampling PIC for the proper performance of all operations at the test site. Receives technical advice from CED and CFE engineers on system and equipment design parameters. Maintains cognizance of test exceptions as documented by the CFE Cognizant engineer and the resolution of same. Concurs with a 11 changes and with the acceptability and reliability of the equipment by signing the OTP.

\section{Core Sampling PIC}

Responsible for the assignment of personnel and directing the operation of the various systems. Controls configuration and access to the test area in order to maintain a safe environment. Aids the Cognizant Engineer in maintaining configuration control. Approves changes to the OTP in terms of operational steps or equipment configuration with concurrence of CED and CFE cognizant engineer and Operations Test Director. Conducts a pre-job safety meeting at the start of each shift during the performance of the OTP. Briefs the personnel on testing to be performed that day and associated hazards.

\section{CFE Cognizant Engineer}

Provides on site technical expertise and advice to the PIC and Test Director as required. Controls the sequence in which the OTP is conducted through the Test Director and with concurrence of CED. Maintains configuration control during testing. Approves any changes to the 0TP. Notes exceptions to testing on the "Exception / Resolution Data Sheet." Resolves exceptions with the concurrence of CED and the assigned Quality Engineer for those exceptions relating to items which initially required Quality verification. Concurs with the acceptability and reliability by signing the OTP. 
Characterization Equipment Design (CED)

Provides on site technical expertise and advice to the PIC and Test Director as required. Advises $\operatorname{Cog}$. Engineer and Test director on equipment capabilities, recommended test sequence changes, and test requirements. Responsible for issuing any Engineering Change Notices (ECN's) required to support maintaining configuration control during testing. Approves any changes to the OTP. Responsible for obtaining additional support from engineering. Reviews and approves test procedure and test report. Obtains Design Authority approval of test procedure and test report. Resolves any design or project related deficiencies.

\section{Core Sampling Operations Management}

Responsible through the Operations Test Director for the overall testing program. Reviews and approves test procedure. Ensures effective safety meeting is held prior to test start. Monitors testing to extent approval may be given for satisfactory equipment operability and reliability.

\section{Core Sampling Operators}

Conducts testing according to the OTP procedure as directed by the Operations PIC. Notifies the PIC of concerns, exceptions and off-normal conditions during testing.

\section{Quality Assurance}

Reviews and approves test procedure to assure compliance with appropriate regulations. Resolves exceptions requiring quality verification jointly with CFE Cognizant Engineer. Quality verification of exceptions is only necessary for those exceptions relating to items which initially required Quality verification.

\section{Safety}

Reviews and approves test procedure to assure compliance with applicable regulations. Monitors testing as appropriate.

\section{CPO Radiological Control}

Supports testing according to the OTP procedure as directed by the Operations PIC. Notifies the PIC of concerns, exceptions and off-normal conditions during testing. Ensures work performed is within the scope of the applicable Radiological Work Permit (RWP). 


\subsection{INFORMATION}

\subsection{TERMS AND DEFINITIONS}

\begin{tabular}{|c|c|}
\hline $\begin{array}{l}\text { CE or COG } \\
\text { CED } \\
\text { CFE } \\
\text { CPO } \\
\text { CW/CCW } \\
\text { DA } \\
\text { OS } \\
\text { EPDT } \\
\text { FGD } \\
\text { FC } \\
\text { FGC } \\
\text { FGWL } \\
\text { HEPA } \\
\text { HBD } \\
\text { HH } \\
\text { OP } \\
\text { OTP } \\
\text { OTR } \\
\text { PG } \\
\text { PIC } \\
\text { PSi/Psid } \\
\text { QA } \\
\text { QC } \\
\text { RLU } \\
\text { RMCS } \\
\text { RWP } \\
\text { SCFM } \\
\text { SOV } \\
\text { SR } \\
\text { TD } \\
\text { TWRS } \\
\text { VAC } \\
\text { XRI }\end{array}$ & $\begin{array}{l}\text { - Core Sampling Cognizant Engineer } \\
\text { - Characterization Equipment Design } \\
\text { - Characterization Field Engineering } \\
\text { - Characterization Project Operations } \\
\text { - ClockWise/Counter ClockWise } \\
\text { - Design Authority } \\
\text { - Drill String } \\
\text { - Electrical Power Distribution Trailer } \\
\text { - Flammable Gas Detector } \\
\text { - Flow Control } \\
\text { - Flammable Gas Concentration } \\
\text { - Flammable Gas Watch List } \\
\text { - High Efficiency Particulate Air } \\
\text { - Hydraulic Bottom Detector } \\
\text { - Hydrostatic Head } \\
\text { - Operator } \\
\text { - Operability Test Procedure } \\
\text { - Operability Test Report } \\
\text { - Purge Gas } \\
\text { - Person In Charge } \\
\text { - Pound per square inch / Psi differential } \\
\text { - Quality Assurance } \\
\text { - Quality Control (inspection) } \\
\text { - Remote Latch Unit } \\
\text { - Rotary Mode Core Sampling } \\
\text { - Radiological Work Permit } \\
\text { - Standard Cubic Feet per Minute } \\
\text { - Solenoid Operated Valve } \\
\text { - Shielded Receiver } \\
\text { - Test Director } \\
\text { - Tank Waste Remediation System } \\
\text { - Volts, Alternating Current } \\
\text { - X-Ray Imager }\end{array}$ \\
\hline
\end{tabular}

\subsection{TEST GUIDANCE}

Authorization for the implementation of this document is controlled by the associated Engineering Data Transmittal. Approval indicates that the testing called out in this procedure will verify the required performance of the equipment and provide the required protection of personnel.

Operability testing will be completed in two phases. Initial testing will confirm that the modified components are functionally acceptable and will operate over their expected range. Records for this portion of the testing will be documented in the left margin and supplied tables within the text of the procedure. The second phase of testing will involve sampling operations using the closed-valve samplers. The second phase of testing will follow a procedure which is similar to that currently used in the field, revised to accommodate flammable gas controls. Portions of this procedure will be adapted and reused given the nature of the 
sampling process. Pertinent operating parameters will be documented on separate "Test Sample Data Sheets" for each sample taken.

Initial instrument calibrations shall be conducted prior to 0perability testing. Calibrations will not be reconfirmed for OTP testing as no advantage will be realized. Field validation of some Preventative maintenance and Calibration procedures will be conducted at the same time as the OTP, but these validations will not be included as a part of the formal OTP.

Discrepancies, deviations, or irregularities involving the test procedure or equipment performance are to be noted, as they occur, on the "Exception / Resolution Data Sheet". An exception number shall be noted in the procedure margin, next to the related test section or step. These exceptions shall be jointly resolved between the Cog Engineer, the Design Authority, the Test Director, and the assigned Quality Assurance

Representative. Quality verification of exceptions is only necessary for those exceptions relating to items which initially required Quality verification. All resolutions to the exceptions must be agreed upon by the responsible personnel, documented on the exception 1 ist, and initialed. Hand written exception sheets may be replaced, if replacement sheets are initialed.

No testing shal1 be done which directly involves faulty equipment. However, at the discretion of the Cog Engineer and with the concurrence of the Test Director, CED and the PIC, tests may proceed on equipment which is not affected by faulty equipment. Any test exceptions caused by equipment failure not associated, directly or indirectly, with the system modifications for flammable gas tank sampling, should be dispositioned as "general maintenance" on the Exception / Resolution Data Sheet.

If, due to testing circumstances, on-site modifications of the test procedures are warranted, written changes ("redlines") may be made by the core sampling PIC with the written approval (initialing in the left margin) of the Test Director, Cog Engineer and CED. These changes must al so be documented on the Exception / Resolution Data Sheet prior to test completion sign-off. Amendments shall be per instructions in WHC-CM-6-1, "Standard Engineering Practices", EP-4.2, "Testing Requirements," Rev. 5, Change 1 .

New operating procedures, written for RMCS operations in flammable gas tanks, are referenced for use as directional information within this OTP. These procedures will be approved for use in OTP testing by the Test Director, Cog Engineer and industrial safety. The procedures will be marked as "DRAFT" to prevent unauthorized use in tank farms. The same procedures will be revised for operational use after a formal procedure validation and finalized procedure approval \& release. Procedure validations will be performed in parallel with OTP testing, but are not part of any OTP acceptance criteria and are not required for 0TP completion sign off. A redlined copy of each of these procedures will be included in the OTR as Appendix 5 for information only. Cog. engineer redlines to these procedures, including the use of "N/A" to mark steps not required for testing, do not require the use of the Exception / Resolution Data Sheet. 


\subsection{REFERENCES}

$\begin{array}{ll}\text { WHC-SD-WM-ETP-177, Rev. } 0 & \begin{array}{l}\text { Engineering Task Plan for Core Sampling in } \\ \text { Flammable Gas Watch List Tanks }\end{array} \\ \text { WHC-SD-WM-FDC-048, Rev. } 0 \quad \begin{array}{l}\text { Functional Design Criteria for Core } \\ \text { Sampling in Flammable Gas Watch List Tanks }\end{array} \\ \begin{array}{ll}\text { WHC-SD-WM-TP-488, Rev. 0 } & \begin{array}{l}\text { ATP/OTP Test Plan for Rotary Mode Core } \\ \text { Sampling in Flammable Gas Tanks }\end{array} \\ \text { WHC-SD-WM-SAD-035, current rev. } & \begin{array}{l}\text { Safety Assessment of RMCS in Flammable Gas } \\ \text { Single Shel7 Tanks }\end{array} \\ \text { WHC-CM-6-1; } & \text { Standard Engineering Practices; } \\ \text { EP-4.2, Rev. 5, Change } 1 & \text { Testing Requirements }\end{array}\end{array}$

\subsection{SAFETY ISSUES}

To reduce the possibility of injury, all persons in the vicinity of the test equipment must be made aware of the following concerns:

Warning - The purge gas piping system on the core sample truck is potentially contaminated. Do not vent nitrogen directly to atmosphere. The RMCS exhauster or other HEPA filtration should be used for nitrogen flow from the purge gas piping system.

Warning - Exercise caution concerning loose clothing and pinch points while working on or near rotating equipment.

Warning - Personal protective equipment should be used during testing, such as safety glasses, gloves, hearing protection and safety shoes, when appropriate.

Warning - At times, nitrogen gas will be supplied to the sample truck at high pressure. Breaking containment of a pressurized cavity will cause a rapid release of gas. All indicators must be observed so that each cavity is vented prior to being opened.

Warning - Avoid contact with liquid nitrogen. The nitrogen in the Liquid Nitrogen Support Trailer nitrogen tank and vaporizer supply line is a liquid and is stored at high pressure and extremely low temperatures $\left(-320^{\circ} \mathrm{F}\right)$. Exposure at these conditions will freeze skin, causing severe "burns."

Warning - Pressure relief venting of the propane supply on the nitrogen trailer can occur unexpectedly. The vent line for the propane is the copper tubing on the right side of the trailer and the outlet is below and at the rear of the trailer. All flammability warnings posted on the nitrogen trailer must be observed.

Warning - If engines need fuel, refuel only when the engines are cool. 
Warning - Stand clear of exhaust pipes on the test equipment.

Warning - The warning sirens on the sample truck are very loud.

Note - Under normal conditions, periodic venting of the nitrogen trailer will occur. Venting is automatic when excessive pressure builds in the nitrogen storage tank. The vent outlet is located near the right rear of the trailer on top of the enclosure.

\subsection{RADIATION AND CONTAMINATION CONTROL}

All testing will be controlled to prevent contamination release, and stand-in materials shall be used to simulate waste tank conditions. test activities must comply with the requirements listed in the RWP issued for this test.

\subsection{QUALITY ASSURANCE}

Quality Assurance shall approve of the Operability Test Procedure prior to its release. A Quality Control representative shall verify all steps requiring $Q C$ verification during testing.

\subsection{SYSTEM ALARM ACTIVATION AND CANCELLATION}

The sample truck is equipped with two alarm systems. The hydraulic bottom detector (HBD) system prevents excessive downward force from being applied to the drill bit. The sequence of events to complete should an HBD alarm go off will be described within the test procedure.

The second alarm system is computer controlled. The computer will warn the operator if conditions are not acceptable. Most of the alarms function in the same way, but because some alarms are more serious than others, the required operator response will vary. The alarms which are critical and require immediate operator action will be forced to occur during testing in section 7.7. The sequence of events to complete should an unanticipated alarm go off, is as follows:

1) NORMAL CONDITION - No lights on or flashing.

- Continue as is.

2) UNACKNOWLEDGED ALARM - Warning light flashes fast.

- Press ACKNOWLEDGE button.

- Make appropriate adjustment.

- Press RESET button.

3) ACKNOWLEDGED ALARM - Warning light stays on.

- Unacceptable condition is still present.

- Make appropriate adjustment.

- Press RESET button. 
4) ALARM NORMALIZED - Warning light flashes slow.

- Unacceptable condition is gone.

- Press RESET button.

- Verify alarm clears.

5) FULL ALARM - Siren and Strobe both go off.

- Unacceptable condition exists for a critical parameter.

- Press ACKNOWLEDGE to silence horn and strobe.

- Correct problem or truck may shut down.

- Press RESET when condition 4 exists.

\subsection{ACCEPTANCE CRITERIA}

Items to be tested in the OTP which are critical, in relation to safe core sampling operations in flammable gas tanks, are part of the critical alarm instrumentation (engine shutdown) system. All of the alarm checks shall be accepted ONLY if they operate within the limits defined in the $S A$ for core sampling in flammable gas tanks (WHC-SD-WM-SAD-035). Flow rate, pressure, and leak rate criteria will be applied to the Purge Gas system.

The remainder of this test verifies basic operation functions of the equipment. Except where otherwise noted, the acceptance criteria for these remaining test sections is based on the operability of the equipment modified for flammable gas tank sampling, functioning in an operational scenario. Each step shall be evaluated and signed off by the cognizant engineer as we 11 as 0perations to verify that the equipment is acceptable for field use.

Qualification testing to validate quantitative reliability data is not a requirement of this test. Reliability of the modified equipment shall be evaluated qualitatively during sampling operations, section 8.0 , as well as throughout this test procedure. Reliability shall be based on the number of evolutions required to ensure operability of the modified equipment. Acceptable reliability based on these evolutions shall be determined by the judgement of the cognizant engineer and the operations manager. The acceptance of the overall reliability of the modifications to the system is documented by signatures on the test completion sign-off sheet.

All persons responsible for signing the test completion sign-off sheet shall perform a joint test group review of the completed procedure to verify technical acceptability of all data and exception resolutions. 


\subsection{RECORDS}

Pertinent operating conditions will be documented where requested in the OTP. Records for the testing of equipment, (section 7), will be recorded within the procedure. The operator, (and other test personnel requested to do so), will initial in the space provided in the left-hand margin upon satisfactory completion of designated tasks. All persons initialing within this procedure (including the Exception / Resolution Data Sheet) will initial and sign the Signature $\log$ Sheet.

Information whose acceptance condition is designated as "For Record Only" may vary. This information may be subject to the situation at hand; therefore, it is left to the equipment operator and cognizant engineer and PIC to determine whether the equipment operates acceptably.

Operating parameters for the sample collection phase of testing, (section 8), will be recorded on a separate "Test Sample Data Sheet" for each sampling cycle. All data recorded on the data sheet is designated "For Record Only".

A post test review meeting will be held within one week of test completion. All test data will be released, as an Operability Test Report, after the conclusion of OTP testing. 


\subsection{PREREQUISITES}

\subsection{EQUIPMENT and SUPPLIES}

\begin{tabular}{|c|c|}
\hline EQUIPMENT UNDER TEST & TEST SUPPORT SUPPLIES \\
\hline $\begin{array}{l}\text { Rotary Mode Core Sample Truck } \\
\text { RMCS Exhauster } \\
\text { Nitrogen Trailer } \\
\text { Portable Electric Generator } \\
\text { Electrical Power } \\
\text { Distribution Trailer } \\
\text { FGD Interlock } \\
\text { Riser Sleeve and Spray Washer } \\
\text { Drill Rod } \\
\text { Core Barrel and Rotary Drill Bit } \\
\text { Riser Equipment and Gaskets } \\
\text { Sampler Change Out Assembly } \\
\text { Non-sparking Tools } \\
\text { Drill String Locking Collar }\end{array}$ & $\begin{array}{l}\text { Breathing Air Compressor } \\
\text { Sample Cask Transport Truck } \\
\text { X-ray Imager } \\
\text { Support Truck, with water, heater \& Pump } \\
\text { Pneumatic Foot Clamp } \\
\text { Cask Stand } \\
\text { Transport Casks with Liners } \\
\text { Hand Levels } \\
\text { Tape Measure } \\
\text { Cask Adapters and Cap } \\
\text { PVC Sleeves } \\
\text { Pull Rod Container } \\
\text { Universal Samplers } \\
\text { Cable Spray Washer and Cap } \\
\text { Plastic Sheeting/Sleeving and Bags } \\
\text { Rubber Matting } \\
\text { Kraft Paper } \\
\text { Permanent Ink Fine Point Marker } \\
\text { Stop Watch } \\
\text { Soap Test Solution } \\
\text { Kamlok Adapters and Caps } \\
\text { (for ouill Rod and Drill string) } \\
\text { Jack Collars } \\
\text { Waste Simulants } \\
\text { Waste Receptacles } \\
\text { Test Pit Modification Equipment } \\
\text { (with riser flanges) }\end{array}$ \\
\hline
\end{tabular}

\subsection{PROCEDURES}

T0-060-345, Liquid Nitrogen Support Trailer and Indeeco Nitrogen Heater Operations

T0-020-900, Onan 150DGFA Generator Set Operation

T0-020-056, Operate the Aeroflow Model 2AN137 Bréathing Air Compressor

T0-020-451, Perform Setup and Takedown of Rotary Truck at Waste Storage Tanks [DRAFT]

T0-080-518, Perform Rotary Core Sampling of Hydrogen/Flammable Gas Watchlist Waste Storage Tanks [DRAFT]

T0-060-342, Operate Rotary Mode Sampling System Exhauster \#4 (EXH-C) [DRAFT] 


\subsection{CONDITIONS}

- The Job Hazard Analysis must be complete prior to test start.

- Pre-job safety meetings shall be held at the start of each shift during testing.

- PRE-START INSPECTION (Appendix 3 Data Sheet) shall be completed EVERY time the RMCS truck is powered up.

- Calibrations and PM's shall be current and complete prior to testing effected equipment.

- All work packages for installation/functional check of flammable gas modifications must be work complete prior to related testing.

- Exhauster post-modification functional test must be complete, per ETP-182 Rev. 1.

- FGD Interlock ATP must be complete, per ATP-HEIF-0001. 


\subsection{TEST PROCEDURE (EQUIPMENT)}

\subsection{EQUIPMENT IDENTIFICATION AND SETUP}

NOTE: The following steps are intended to verify all fittings and receptacles mate properly. If a connection was made previously, VERIFY connection and initial step. Refer to the setup procedure listed in 6.2 if connection or grounding details are required.

OP/CE 7.1 .1

POSITION RMCS equipment, listed in the table below, in a convenient location to allow testing.

OPICE

7.1 .2

PIC or Cog Engineer, RECORD the identification numbers for the major components used in this procedure in the table below. Use the blank lines to record any changes made (record test sections effected by the change).

\begin{tabular}{|l|l||}
\hline COMPONENT & $\begin{array}{c}\text { IDENTIFICATION * } \\
\text { NUMBER }\end{array}$ \\
\hline Core Sample Truck & \\
\hline Exhauster & \\
\hline Flammable Gas Detector (FGD) Interlock & \\
\hline Liquid Nitrogen Support Trailer & \\
\hline Breathing Air Compressor & \\
\hline Portable Generator & \\
\hline Electrical Power Distribution Trailer (EPDT) & \\
\hline Service Trailer & \\
\hline Support Truck & \\
\hline X-Ray Imager (XRI) & \\
\hline & \\
\hline & \\
\hline & \\
\hline
\end{tabular}

* For equipment identification, use HO\# or other unique identifier.

OPICE $\quad 7.1 .3$ CONNECT the electrical grounding wires from the generator and EPDT to an acceptable ground at the test site. 

OP/CE $\quad 7.1 .4$ CONNECT the electrical grounding wire from the service trailer to an acceptable ground at the test site.
OP/CE _ - 7.1.5 CONNECT the electrical grounding wire from the exhauster to an acceptable ground at test site.
OP/CE___ 7.1 .6 CONNECT electrical grounding wire from the FGD Interlock to an acceptable ground on riser flange.

OPICE _ - 7.1.7 CONNECT intrinsic safety barrier ground wires from the sample truck to an acceptable ground on riser flange.

OP/CE/OC___ 7.1 .8 VERIFY resistance between intrinsic safety barrier ground lug and riser flange ground is 1 ohm or less.

OPICE _ 7.1.9 CONNECT the EPDT to the generator using the cable real on the EPDT.

OPICE -7.1 .10$

CONNECT the $120 / 240$ volt power cable to the sample truck from the EPDT. The receptacle is on the driver's side of the truck, near the ladder on the stationary platform.

OPICE _ -7.1 .11$

CONNECT the air compressor to the EPDT. The air compressor is attached to the core sample truck frame on the passenger side beneath the rotating platform.

OP/CE__ 7.1 .12 CONNECT the service trailer to the EPDT with the cable located on the EPDT.

OPICE

OP/CE,$\quad 7.1 .14$

OP/CE

7.1 .15

OP/CE

7.1 .16

OP/CE

7.1 .17

OP/CE

7.1 .18

OP/CE

7.1 .19

OPICE

7.1 .20
CONNECT the X-Ray Imager to the EPDT with the cable located on the X-Ray Imager.

CONNECT the 240 volt power cable to the water heater receptacle on the support truck.

ENSURE exhauster equipment is connected between exhauster skid and test riser flange, including flexible duct, flange \& adapter rings, instrument stand, and seal pot outlet 1 ine.

ENSURE signal and power cables are connected between FGD Interlock components (power distribution skid, carts, sampler spool piece/junction box, and riser instrument stand).

CONNECT the signal cable from the FGD interlock cart to the exhauster.

CONNECT a 120 volt control cable from each FGD interlock cart to the exhauster.

CONNECT the pressure shutdown control cable from the exhauster skid to the exhaust riser instrument stand.

CONNECT the 480 volt power cable from the EPDT to the FGD interlock power distribution skid. 
OP/CE__ 7.1.21 CONNECT the 480 volt power cable from the FGD interlock power distribution skid to the exhauster.

OP/CE__ 7.1 .22 CONNECT the 120 volt power cable from the nitrogen trailer to the diesel generator (the propane generator on the nitrogen trailer is not required for this test).

OP/CE__ 7.1.23 CONNECT the 480 volt power cable between the breathing air compressor and the generator.

OP/CE__ 7.1.24 PLUG IN the 480 volt space heater to the EPDT.

$\mathrm{OP} / \mathrm{CE}$ _ $\quad 7.1 .25$ CONNECT the exhauster interlock cable from the exhauster to the sample truck.

NOTE: In the following step, a $7 \mathrm{ft}$. test unique riser sleeve will be used instead of the $15 \mathrm{ft}$. operational riser sleeve.

OP/CE _ _ 7.1 .26 CONNECT the core sampling riser equipment to the test pit drilling riser.

OP/CE__ 7.1.27 CONNECT the nitrogen supply line from the nitrogen trailer to the sample truck. The receptacle on the truck is located below the platform by the driver's door.

OP/CE___ 7.1.28 CONNECT the nitrogen supply line from the nitrogen trailer to the exhauster. The receptacle on the exhauster is next to the fan motor housing.

OP/CE_ _ 7.1.29 CONNECT the nitrogen VENT TO TANK 1 ine from the sample truck to the vent port on the riser sleeve.

OP/CE__ _ 7.1.30 CONNECT the nitrogen RISER SLEEVE PURGE 1ine from the sample truck to the drill rod washer.

OP/CE__ 7.1.31 CONNECT the spray wash water supply hose from the support truck to the drill rod spray wash connection on the riser sleeve flange.

OPICE _ 7.1.32 DISCONNECT the spray wash water supply hose from the riser sleeve flange, and CONNECT hose to the riser sleeve spray wash connection on the riser sleeve spray washer assembly.

OPICE __ 7.1.33 VERIFY unique connections are provided for both the drill string and riser equipment nitrogen purge systems and spray wash systems, as well as the hydrostatic head systems for the drill string and shielded receiver.

OPICE _ 7.1.34 DISCONNECT the nitrogen supply line from the sample truck, and the spray wash water supply hose from the riser sleeve spray washer. 


\subsection{CORE SAMPLE TRUCK START UP}

NOTE: When truck electronics are powered up, a 20 min warm up period is required prior to operation.

NOTE: Whenever truck electronics are powered up without establishing nitrogen supply pressure and Z-purge flow, the LOW PURGE GAS PRESSURE and SR WEATHER COVER PG PRESSURE alarms will sound. These alarms should be acknowledged and no further action taken prior testing in sections $7.6 \& 7.7$.

OPICE___ 7.2.1 OPERATE the generator as required throughout testing. (See operating procedures listed in 6.2 )

OPICE__ 7.2.2 ACTIVATE all breakers on the POWER DISTRIBUTION pane1, located on the control console.

OP/CE _ CONTROL paneTs.

OPICE__ 7.2.4 TURN the air compressor $O N$ and allow it to run until it automatically shuts off.

OPICE _ _ 7.2.5 START the drill rig engine as directed below (operate the drill engine as required throughout testing):

7.2.5.1 ENSURE that the five (5) HYDRAULIC JACK leveling control valves are closed.

7.2.5.2 PLACE the 4-way manual valve in the HEAD position.

7.2.5.3 ENSURE that the clutch is DISENGAGED and the chuck is CLOSED.

7.2.5.4 PUSH and HOLD the black start button and TURN the key clockwise to start the drill engine. ADJUST the throttle to approximately 1500 RPM. 


\subsection{DRILL RIG MANEUVERING}

NOTE: The sample truck is raised by hydraulic rams, located at the front and rear of the truck, and is leveled using portable hand levels. The center jacks, consisting of two additional rams located on each side of the truck, are used to stabilize the truck for platform rotation. The center jacks are not designed to withstand heavy loads, and should only be lowered after lowering the front and rear lifting jacks. When leveling the truck, lower the rams slowly so that the truck is lifted uniformiy. The hydraulic controls associated with leveling are the 4way manual control valve and the turn valves which control flow to each of the jacks.

OPICE__ 7.3.1 ENSURE hydraulic hoses, lines, and fittings are clean and do not exhibit any visible leakage.

OP/CE _ 7.3.2 LEVEL the sample truck by referring to the set up procedure listed in 6.2 , or by using the following steps:

7.3.2.1 PLACE the 4-way control valve in the FLOAT position.

7.3.2.2 CONNECT the hydraulic leveling hoses from the main reservoir to the leveling system. The hoses are stored and coupled near the right rear leveling ram.

7.3.2.3 PLACE the 4-way control valve in the RAISE position.

7.3.2.4 LOWER the front and rear lifting jacks to the ground using the control valves.

7.3.2.5 LEVEL the truck at convenient height for testing.

7.3.2.6 LOWER the two side stabilizer jacks to the ground.

7.3.2.7 INSTALL the jack collars on each jack.

7.3.2.8 PLACE the 4-way control valve in the FLOAT position.

7.3.2.9 DISCONNECT and STORE the hydraulic leveling hoses. 
WARNING: For the following platform rotation, and throughout testing, always ensure that the drill head, SR, and drill rig are positioned to avoid equipment damage prior to moving the rotating platform. Whenever practical, the drill head and SR should be in the up position and the drill rig traversely centered before making any rotation.

NOTE: For the following steps in this test, the Control Select Panel is used to select either pendant or control console hydraulic controls. When in pendant control, traverse and fast rotation are available using the control console as well as the pendant. For all other control/command combinations, the control selected is enabled and the other control is locked out.

OP/CE _ - 7.3.3 VERIFY the SLOW ROTATION mode for both the console and pendant in both the $\mathrm{CW}$ and $\mathrm{CCW}$ directions. Rotation should automatically stop at the limits.

OP/CE _ 7.3.4 VERIFY the FAST ROTATION mode for both the console and pendant in both the $\mathrm{CW}$ and $\mathrm{CCW}$ directions. Rotation should start after the alarm sounds and a 3 second delay, and should automatically stop at the limits.

OPICE _ 7.3.5 ROTATE the platform so that the SR is at the rear of the truck.

OP/CE ___ 7.3.6 HOLD the console TRAVERSE switch to FORWARD to fully extend the SR then RETRACT. Also VERIFY operation of the pendant TRAVERSE controls.

OPICE _ - 7.3.7 EXTEND the SR over the edge of the platform. VERIFY the SR UP/DOWN operation on the control panel and pendant.

OPICE - 7.3.8 ENSURE the SR is in the up position, and drill rig is centered.

OPICE _ 7.3.9 ROTATE the platform to position the drill rig to the rear.

OP/CE__ 7.3.10 VERIFY the slew operation for both console and pendant controls. (The drill should slide about 4 inches from center each way.)

OP/CE _ 7.3.11 HOLD the console TRAVERSE switch in the REVERSE position to fully extend the drill rig then RETRACT. Also VERIFY operation of the pendant TRAVERSE controls.

OPICE__ 7.3.12 LOWER the drill head while monitoring the digital depth display and mechanical position indicator. VERIFY one foot change on the digital depth display corresponds to approximately one foot change on the mechanical position indicator. 
$\mathrm{OP} / \mathrm{CE}$

7.3 .13

7.3 .14

$-7.3 .15$

OP/CE

$\mathrm{OP} / \mathrm{CE}$

7.3 .16
RAISE the drill head while monitoring the digital depth display and mechanical position indicator. VERIFY one foot change on the digital depth display corresponds to approximately one foot change on the mechanical position indicator.

LOWER the drill head while monitoring the penetration rate display and mechanical position indicator. Using a stopwatch, VERIFY one inch per second drill head travel corresponds to approximately one inch per second penetration rate on the digital display.

RAISE the drill head while monitoring the penetration rate display and mechanical position indicator. Using a stopwatch, VERIFY one inch per second drill head travel corresponds to approximately one inch per second penetration rate on the digital display.

VERIFY hydraulic hoses, lines, and fittings do not exhibit any visible leakage.

\subsection{SAMPLE ACTUATOR / HBD (HYDRAULIC BOTTOM DETECTOR)}

The grapple hoist motor control is interlocked to the grapple hoist load cell. The hoist motor will automatically stop when the load cell detects a load $\geq 250$ lbs.
$\mathrm{OP} / \mathrm{CE}+7.4 .1$
VERIFY the load cell loop calibration is completed using the above set point (Ref. 6-ES-415).
$\mathrm{OP} / \mathrm{CE} \ldots 7.4 .2$
$\mathrm{OP} / \mathrm{CE} \ldots \quad 7.4 .3$
POSITION the platform to allow actuator testing.

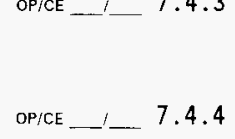
PLACE the mode switch to GRAPPLE LOWER and HOLD the HOIST switch in the DOWN position to lower the grapple through the quil1 rod adapter.

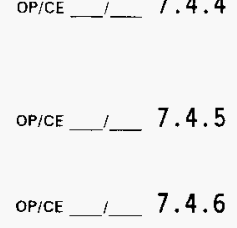
TURN OFF the grapple load cell power switch and VERIFY the hoist will not operate, then TURN ON the grapple load cell power switch.
TEST the hoist speed control at various settings, then SET a moderate hoist speed for further testing.
COMPLETE the steps below to verify slack detection capability. The hoist motor should stop when the load cell display is approximately 9 to 12 pounds.
7.4.6.1 PLACE the grapple mode switch to GRAPPLE LOWER, then HOLD the HOIST switch in the DOWN position to lower the grapple until slack in the cable automatically stops the hoist motor. 7.4.6.2 VERIFY HYDRAUL IC INTERLOCK light on the control console
is ON. 
CAUTION: If the hydraulic interlock does not function properly, upward movement of the ram, when the grapple cable is slack, can cause cable misalignment on the hoist drum. During the following interlock test DO NOT allow ram movement to cause more than $1 / 4$ inch change in ram position indication while the HYDRAULIC INTERLOCK light is ON.

7.4.6.3 VERIFY hydraulic rams cannot be raised.

7.4.6.4 VERIFY HYDRAULIC INTERLOCK light remains ON.

7.4.6.5 REMOVE the slack by placing the mode switch to SAMPLING POSITION and holding the HOIST switch to UP until the hoist stops when slack is removed.

7.4.6.6 VERIFY HYDRAULIC INTERLOCK light is OFF.
OP/CE 7.4 .7
PLACE the grapple mode switch to GRAPPLE LOWER then HOLD the HOIST switch to UP to raise the grapple into the quill rod.
OP/CE
INSERT a pintle rod into the grapple.
$\mathrm{OP} / \mathrm{CE}$
7.4 .9
HOLD the HOIST switch in the UP position to raise the grapple until the pre-pintle release switch stops the hoist.
OP/CE
7.4 .10
VERIFY that the HYDRAULIC INTERLOCK light is ON.

CAUTION: If the hydraulic interlock does not function properly, downward movement of the ram, while the grapple is in the UP position, can destroy the actuator system. During the following interlock test DO NOT al low ram movement to cause more than $1 / 4$ inch change in ram position indication or to exceed 200 pounds on load cel1 reading, while the HYDRAULIC INTERLOCK 1 ight is $0 N$.

OP/CE _._. 7.4.11 VERIFY hydraulic rams cannot be lowered.

OP/CE - 7.4.12 HOLD the pintle release switch to the UP LIMIT BYPASS position and the HOIST switch to UP until the pintle rod releases.

OPICE _ _ 7.4.13 VERIFY HYDRAULIC INTERLOCK 1 ight remains ON.

OPICE _- 7.4.14 DEPRESS the DOWN BYPASS button then HOLD the HOIST switch to DOWN to lower the grapple until the HYDRAULIC INTERLOCK light goes out.

OP/CE - 7.4.15 ENSURE 5 to 10 feet of drill string is installed into the test pit drilling riser and connected to the quill rod.

OP/CE/QC

7.4 .16

VERIFY the maximum speed of the grapple hoist is $\leq 1$ $\mathrm{ft} / \mathrm{sec}$ by performing the following steps:

7.4.16.1 RECORD drill string length (including all sections below the grapple) in the following table. 
7.4.16.2 LOWER the grapple, at maximum speed, to the bottom of the drill string, using a stop watch to measure time required to travel the length of drill string.

7.4.16.3 RECORD elapsed time in the table below (TRIAL 1).

7.4.16.4 RAISE the grapple, at maximum speed, to the top of the drill string, using a stop watch to measure time required to travel the length of drill string.

7.4.16.5 RECORD elapsed time in the table below (TRIAL 2).

7.4.16.6 CALCULATE and RECORD grapple hoist speeds in the table below.

\begin{tabular}{||l|l|c|c|}
\hline \multicolumn{1}{|c|}{ PARAMETER } & \multicolumn{1}{|c|}{ CONDITION } & TRIAL 1 & TRIAL 2 \\
\hline \hline Distance & feet, FOR RECORO ONLY & & \\
\hline Time & seconds, FOR RECORD ONLY & & \\
\hline \hline Speed & $\mathrm{ft} / \mathrm{sec}$, MUST BE $\leq 1$ & & \\
\hline
\end{tabular}

7.4.17 TEST the HBD as directed below:

NOTE: On the final sample, when the full ram stroke is complete or should the drill bit contact the bottom of the tank, the HBD alarm will go off and flow to the rams will automatically be reversed; thus separating the drill bit from the bottom of the tank.
OP/CE
7.4 .17 .1
POSITION suitable material beneath the drill head for HBD testing.

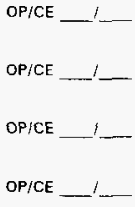
OP/CE
OP/CE
$\mathrm{OP} / \mathrm{CE}$
OP/CE
7.4.17.2 PLACE the 4-way valve in the HEAD position.
7.4.17.3 ENSURE that the DOWN hydraulic control valve is CLOSED.
7.4.17.4 OPEN the UP ram control about $1 / 3$ of a turn.
7.4.17.5 TURN the LOWER RAM PRESSURE/SET POINT switch on the instrumentation enclosure to SET POINT, then ADJUST the LOWER RAM PRESSURE SET POINT dial to 80 to $120 \mathrm{psig.}$
7.4.17.6 RECORD the set point pressure, as indicated on the LOWER RAM PRESSURE/SET POINT readout, in the table below.
7.4.17.7 PUSH and HOLD the START BYPASS button on the HBD Pane 1 .
7.4.17.8 PLACE the 4-way control valve in the LOWER position.
7.4.17.9 When the UP and DOWN ram gauge pressures stabilize, TURN the HBD DRILL key ON then RELEASE the START BYPASS button. 


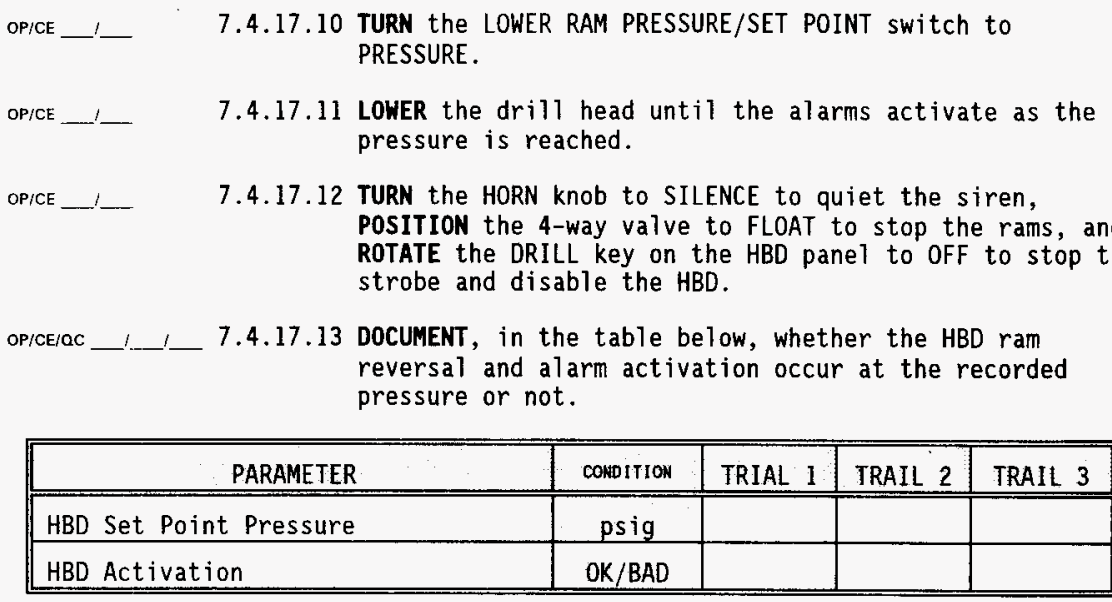

OP/CE

7.4.17.14 RETURN to step 7.4.15 and REPEAT process at two additional set point pressures.

\subsection{SHIELDED RECEIVER / REMOTE LATCH UNIT}

OPICE _ 7.5.1 ROTATE the platform to allow shielded receiver (SR) and remote latch unit (RLU) testing.

OP/CE/OC

7.5.2 VERIFY the maximum speed of the sampler hoist is $\leq 1 \mathrm{ft} / \mathrm{sec}$ by performing the following steps:

7.5.2.1 LOWER the RLU into the drill string.

7.5.2.2 RECORD encoder display reading in the following table (TRIAL 1).

7.5.2.3 LOWER the RLU, at maximum speed, to the bottom of the drill string, using a stop watch to measure time required to travel the length of drill string.

7.5.2.4 RECORD elapsed time and encoder display reading in the following table (TRIAL 1).

7.5.2.5 RAISE the RLU, at maximum speed, to the top of the drill string, using a stop watch to measure time required to travel the length of drill string.

7.5.2.6 RECORD elapsed time and encoder display reading in the following table (TRIAL 2).

7.5.2.7 CALCULATE and RECORD sampler hoist distance and speeds in the following table. 
WHC-SD-WM-OTP-212 Rev. 0

\begin{tabular}{|l|l|c|c||}
\hline \multicolumn{1}{|c|}{ PARAMETER } & \multicolumn{1}{|c|}{ CONOITION } & TRIAL 1 & TRIAL 2 \\
\hline \hline Encoder, start & feet, FOR RECORD ONLY & & \\
\hline Encoder, end & feet, FOR RECORD ONLY & & \\
\hline Time & seconds, FOR RECORD ONLY & & \\
\hline \hline Distance & feet, FOR RECORD ONLY & & \\
\hline Speed & $\mathrm{ft} / \mathrm{sec}$, MUST BE $\leq 1$ & & \\
\hline
\end{tabular}

OP/CE

7.5.3

TURN OFF the SR load cell power switch and VERIFY the hoist will not operate, then TURN ON the SR load cell power switch.

7.5.4 PERFORM the following steps to test the load cell:
OP/CE
7.5.4.1 LOWER the RLU through the SR.
OP/CE
7.5.4.2 RECORD the load-cell weight in the following table.
OP/CE
7.5.4.3 ATTACH an empty sampler to the RLU.
OP/CE
7.5.4.4 RECORD the load-cell weight in the following table.
OP/CE
7.5.4.5 CALCULATE and RECORD below the sampler weight.

\begin{tabular}{|c|c|c|}
\hline 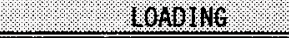 & 603011104 & 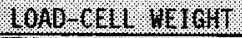 \\
\hline RLU + Sampler Weight & 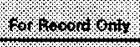 & \\
\hline RLU Weight & 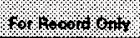 & \\
\hline Sampler Weight & 6010.001 .611$. & \\
\hline
\end{tabular}

\subsubsection{TEST the latch unit as directed below:}

OP/CE - 7.5.5.1 RAISE the RLU and sampler into the SR, then ATTACH a core barrel and drill bit to the SR.

OP/CE ।

OP/CE

7.5 .5 .3

7.5 .5 .2

LOWER the sampler into the core barrel. The hoist will automatically stop when cable slack is detected. VERIFY load cell display is approximately 20 pounds when the hoist motor stops.

OBSERVE the load cell display as the RLU releases the sampler. The sampler is released when the load cell weight is no longer changing (approximately 2 minutes).

OPICE

OP/CE
7.5 .5 .5

7.5.5.4 RAISE the RLU into the sight glass and VERIFY that the sampler is not attached.

LOWER the RLU onto the sampler (the hoist will automatically stop when cable slack is detected). 


\section{OP/CE \\ 7.5.5.6 RELEASE the hoist switch. \\ OPICE \\ 7.5.5.7 SET hoist speed control to 0\%, HOLD hoist switch in UP position, and slowly INCREASE speed control to raise the sampler into the sight glass. \\ OP/CE \\ 7.5.5.8 VERIFY that the sampler is attached to the RLU. If sampler is NOT attached, repeat the above three steps one additional time.
OP/CE
7.5 .5 .9
RETURN to step 7.5 .3 and REPEAT process a minimum of ten times. \\ OPICE___ 7.5.5.10 POSITION the RLU, with sampler attached, over transport cask. \\ OP/CE _- 7.5.5.11 LOWER the sampler into the cask and RELEASE the sampler from the RLU.}

\subsection{NITROGEN SUPPLY SYSTEM}

OPICE _ 7.6.1 ENSURE all manual purge gas flow control valves on the truck are closed and the nitrogen supply line from the nitrogen trailer to the sample truck is disconnected. The receptacle on the truck is located below the platform by the driver's door.

OPICE__ 7.6.2 For each of the switch settings shown in the below table, VERIFY the proper response on indicator light panel.

\begin{tabular}{|c|c|c|c|c|c|c|c|c|c|}
\hline \multicolumn{4}{|c|}{ SWITCH SELECTIONS } & \multirow{2}{*}{$\begin{array}{l}\text { Type of } \\
\text { Cormand }\end{array}$} & \multicolumn{4}{|c|}{ INDICATOR LIGHT } & \multirow{2}{*}{$\frac{\text { CONDITION }}{\text { OK/BAD }}$} \\
\hline $\begin{array}{c}\text { Purge } \\
\text { gas }\end{array}$ & $\begin{array}{l}\text { Pressurize } \\
\text { shielded } \\
\text { receiver }\end{array}$ & $\begin{array}{l}\text { Pressurize } \\
\text { drill } \\
\text { string }\end{array}$ & Mode & & $\begin{array}{l}\text { SOV } \\
14 \\
\text { PG }\end{array}$ & $\begin{array}{l}\text { SOV } \\
15 \\
\text { SR }\end{array}$ & $\begin{array}{l}\text { SOV } \\
16 \\
\text { DS }\end{array}$ & $\begin{array}{c}\text { Sov } \\
17 \\
\text { vent }\end{array}$ & \\
\hline OFF & OF F & OFF & Drill & VALID & OFF & OFF & OFF & OFF & \\
\hline OFF & ON & OFF & Drill & INVAL ID & $\mathrm{Flash}$ & Flash & flash & Flash & \\
\hline OFF & OFF & ON & Drill & INVALID & $\mathrm{Flash}$ & Flash & Flash & Flash & \\
\hline OFF & ON & ON & Drill & INVALID & Flash & Flash & Flash & Flash & \\
\hline ON & OFF & OFF & Drill & VALID & ON & OFF & OFF & ON & \\
\hline ON & ON & OFF & Drill & INVAL ID & ON & Flash & Flash & $\mathrm{ON}$ & \\
\hline ON & OFF & ON & Drill & INVALID & ON & $\mathrm{Flash}$ & Flash & ON & \\
\hline ON & ON & ON & Drill & INVAL ID & ON & $\mathrm{Flash}$ & Flash & ON & \\
\hline OFF & OFF & OFF & Sample Rec. & VALID & OFF & OFF & OFF & ON & \\
\hline ON & OFF & OFF & Sanple Rec. & INVALID & Flash & Flash & $\mathrm{Flash}$ & ON & \\
\hline OFF & $\mathrm{ON}$ & OFF & Sample Rec. & VALID & OFF & ON & OFF & OFF & \\
\hline ON & $\mathrm{ON}$ & OFF & Sample Rec. & INVALID & Flash & ON & Flash & Flash & \\
\hline OFF & OFF & ON & Sample Rec. & VALID & OFF & OFF & $\mathrm{ON}$ & $\mathrm{ON}$ & \\
\hline ON & OFF & $\mathrm{ON}$ & Sample Rec. & INVALID & Flash & Flash & $\mathrm{ON}$ & $\mathrm{ON}$ & \\
\hline off & ON & ON & Sample Rec. & VALID & OFF & ON & $\mathrm{ON}$ & OFF & \\
\hline ON & $\mathrm{ON}$ & ON & Sample Rec. & INVAL ID & Flash & DN & ON & Flash & \\
\hline
\end{tabular}


OP/CE _ 7.6.3 RETURN switch settings to OFF and DRILL.

OP/CE/CC _ _ 7.6.4 ENSURE the purge gas piping system soap solution leak test is complete. Acceptance criteria is: no visible leakage.

RECORD test document or work package number:

OPICE/OC , 1 7.6.5 ENSURE the riser sleeve nitrogen supply soap solution leak test and flow measurements are complete. Acceptance criteria is: no visible leakage, and measured flow is $\geq 2 \mathrm{scfm}$ at 40 psid. RECORD test document or work package number:

OPICE _ 7.6.6 CONNECT the nitrogen supply line from the nitrogen trailer to the sample truck.

OP/CE__ 7.6.7 FOLLOW the operating procedure (1isted in 6.2) to set up and start the nitrogen trailer system.

OP/CE/OC___ 7.6.8 TEST the Z-purge system as directed below:

7.6.8.1 ENSURE the Z-purge metering valve, located on the shielded receiver lifting frame, is fully open.

7.6.8.2 VERIFY pressure reading on Z-purge pressure gauge is above 0.5 inches water gauge.

7.6.8.3 RESET the SR WEATHER COVER PG PRESSURE alarm, located in the instrument enclosure.

7.6.8.4 ENSURE nitrogen supply line is leak checked (using soaptype solution) between the pressure switch fitting and the weather cover penetration. No visible leakage is allowed.

7.6.8.5 CLOSE the metering valve to reduce pressure to approximately 0.3 inches water gauge.

7.6.8.6 VERIFY that alarm horn sounds and strobe flashes, and that the SR WEATHER COVER PG PRESSURE alarm light flashes.

7.6.8.7 OPEN metering valve.

7.6.8.8 When pressure reading on Z-purge pressure gauge is above 0.5 inches water gauge, PRESS the ALARM RESET button.

7.6.8.9 VERIFY that the SR WEATHER COVER PG PRESSURE alarm 1 ight goes out. 
Warning - The purge gas piping system on the core sample truck is potentially contaminated. Do not vent nitrogen directly to atmosphere. The RMCS exhauster or other HEPA filtration should be used for nitrogen flow from the purge gas piping system.

\begin{tabular}{|c|c|c|}
\hline OP/CE _.. & 7.6 .9 & $\begin{array}{l}\text { ENSURE riser equipment is connected to rock slinger pit } \\
\text { modification and all ducting and flex hoses on the pit } \\
\text { modification are secured. }\end{array}$ \\
\hline OP/CE _ 1 & 7.6 .10 & $\begin{array}{l}\text { ENSURE the sampler change out assembly and the VENT TO T } \\
\text { nitrogen hose are connected to the riser equipment. }\end{array}$ \\
\hline $\mathrm{OP} / \mathrm{CE}$ & 7.6 .11 & $\begin{array}{l}\text { ENSURE the exhauster is connected to test riser and is } \\
\text { operating. }\end{array}$ \\
\hline$/ \mathrm{CE}$ & 7.6 .12 & $\begin{array}{l}\text { VERIFY operation of the shie } \\
\text { psig) indicator light by per }\end{array}$ \\
\hline
\end{tabular}

7.6.12.1 ENSURE Shielded Receiver is connected to the sampler change out assembly, and SR Ball Vaive is closed.

7.6.12.2 TURN PRESSURIZE SHIELDED RECEIVER to ON, and MODE switch to sample recovery.

7.6.12.3 INCREASE the SHIELDED RECEIVER PRESSURE unti1 green SHIELDED RECEIVER PRESSURE 1 ight goes off (about 0.2 psig).

7.6.12.4 Slowly OPEN ball valve to decrease pressure, and VERIFY the green SHIELDED RECEIVER PRESSURE light comes back on when the SHIELDED RECEIVER PRESSURE display reads approximately 0 psig.

7.6.12.5 TURN PRESSURIZE SHIELDED RECEIVER to OFF.

OPICE _._. 7.6.13 VERIFY operation of the drill string pressure (zero psig) indicator light by performing the following steps:

7.6.13.1 ENSURE DRILL STRING SUPPLY hose is in the dritiing mode (disconnected and stowed on reel).

7.6.13.2 TURN PRESSURIZE DRILL STRING to ON, and MODE switch to sample recovery.

7.6.13.3 INCREASE the pressure until green DRILL STRING PRESSURE light goes off (about $0.2 \mathrm{psig}$ ).

7.6.13.4 Slowly OPEN crossover manual ball valve (connecting DRILL STRING SUPPLY and VENT TO TANK lines) to decrease pressure, and VERIFY the green DRILL STRING PRESSURE light comes back on when the DRILL STRING PRESSURE display reads approximately 0 psig. 


\subsubsection{TURN PRESSURIZE DRILL STRING switch to OFF.}

OPICE__ 7.6.14 VERIFY operation of the purge gas pressure (zero psig)

indicator light by performing the following steps:

7.6.14.1 ATTACH a core barrel, with sampler and bit installed, to the quill rod and POSITION in riser equipment.

7.6.14.2 TURN PURGE GAS switch to ON, and MODE switch to drill.

7.6.14.3 INCREASE the PURGE GAS PRESSURE until green PURGE GAS PRESSURE light goes off (about 0.3 psig).

7.6.14.4 DECREASE pressure and VERIFY the green PURGE GAS PRESSURE light comes back on when the PURGE GAS PRESSURE display reads approximately 0 psig.

7.6.14.5 TURN purge gas switch to OFF.

OP/CE _ 7.6.15 VERIFY operation of the nitrogen supply low pressure alarm by performing the following steps:

7.6.15.1 ENSURE DRILL STRING SUPPLY hose is in the drilling mode (disconnected and stowed on reel).

7.6.15.2 SET PRESSURIZE DRILL STRING to ON, and MODE switch to sample recovery.

7.6.15.3 SHUT DOWN the nitrogen trailer per operating instructions.

7.6.15.4 VENT nitrogen supply pressure to below 60 psi. After approximately 5 seconds VERIFY the SIREN sounds, the STROBE flashes, and the LOW PURGE GAS PRESSURE Iight comes on and flashes fast.

7.6.15.5 PRESS the ALARM ACKNOWLEDGE button and TURN PRESSURIZE DRILL STRING to OFF. 


\subsection{CRITICAL ALARM CHECKS}

The sample truck computer continuously monitors several conditions during operation of the truck. Some of the information is monitored to warn the operator of abnormal conditions which are not related to the primary safety function of the RMCS and are not considered part of the critical alarms tested in this section. These alarm conditions have been previously tested and function the same as on RMCS trucks not modified for flammable gas tanks. Should an alarm of this nature occur during testing, the operator should simply take action to correct the situation. The temperature related alarms are described below.

The operating temperature of the instrumentation assembly must be maintained in order to provide accurate data. To accomplish this, the enclosure is equipped with an air conditioner and heater. Power will not be supplied to the enclosure instruments until the enclosure is heated to above $55^{\circ} \mathrm{F}$, or cooled to below $100^{\circ} \mathrm{F}$. If the enclosure temperature is above $90^{\circ} \mathrm{F}$ or below $50^{\circ} \mathrm{F}$, the panel light will flash fast. If the condition persists for 60 seconds, the horn and strobe will go off. If purge gas temperatures below $10^{\circ} \mathrm{F}$ or above $140^{\circ} \mathrm{F}$ are detected, the horn and strobe will go off and the panel light will flash fast.

If the computer detects an operating condition which may indicate equipment failure or other unacceptable condition which requires immediate action, the drill engine will automatically initiate an immediate shutdown. Immediate shut down is defined in the SA as "the time it takes for the PLC to send a shutdown signal to the drill engine upon receipt of a valid shutdown signal with no additional programmed-delay. It is understood that the determination of a valid alarm signal requires approximately 2 seconds" (WHC-SD-WM-SAD-035). These alarms are considered the critical alarms, and are intentionally activated in the following tests.

WARNING: The purge gas piping system on the core sample truck is potentially contaminated. Do not vent nitrogen directly to atmosphere. The RMCS exhauster or other HEPA filtration must be used to exhaust potentially contaminated purge gas used during all critical alarm tests, including hydrostatic head and riser sleeve purge gas. Refer to operating procedure listed in 6.2 for exhauster start up sequence.

\subsubsection{DRILL RPM ALARMS}

Drill bit rotation is a critical operating parameter. The bit speed is limited to $\mathbf{5 5} \mathbf{~ r p m}$. If the rpm exceeds 55 an immediate shutdown will be initiated: the horn and strobe will go off and the drill rig will shut down. The low RPM alarm is used by the PLC to activate rotary mode alarms. If the rpm is less than 2 the rotary mode alarms are not active.

OP/CE

$\mathrm{OP} / \mathrm{CE}$

7.7 .1 .1

7.7 .1 .2
VERIFY the drill RPM loop calibration is completed using the above set points (Ref. 6-ES-437).

ENSURE closed-valve sampler and drill bit are installed in drill string and drill string is positioned in riser equipment. 


\section{OPICE - ATTACH quill rod to drill string. \\ $\mathrm{OP} / \mathrm{CE}$ \\ 7.7 .1 .4 \\ OP/CE \\ OP/CE \\ OP/CE \\ 7.7 .1 .8 \\ 7.7 .1 .5 \\ 7.7 .1 .6 \\ 7.7 .1 .7}

WARNING: Do not open the chuck while it is rotating nor start rotation while the chuck is open. Keep the chuck closed except when connecting to or from the drill string.
OP/CE
7.7.1.9
VERIFY that the chuck is CLOSED.
$\mathrm{OP} / \mathrm{CE}$
7.7 .1 .10
ADJUST the ram hydraulic control valves, as necessary throughout the remainder of this test, to maintain a penetration rate greater than 0.75 inches per minute.
OP/CE
7.7 .1 .11
OP/CE/QC
7.7 .1 .12
OPICE
OP/CE
7.7 .1 .15
OP/CE/QC
7.7 .1 .16
OP/CE
7.7.1.17
OP/CE
7.7 .1 .18
PLACE the transmission in gear and ENGAGE the clutch.
ADJUST the engine throttle to set a drill speed near 60 rpm. VERIFY that the HORN sounds, the STROBE flashes, the HIGH RPM light flashes, and the truck immediately shuts down (acknowledge the alarm as it sounds.)
7.7.1.13 VERIFY the shutdown light on the DR box is off and remains off for approximately 10 minutes after shutdown.
7.7.1.14 Have the instrument tech. DISCONNECT the instrument cable to one of the RPM sensors. clutch, RESTART the engine, and RESET alarm.
ENGAGE the clutch and increase the RPM to near 60 RPM. VERIFY alarm sounds for high RPM, and that the truck immediately shuts down (acknowledge the alarm as it sounds).
Within 10 minutes after shutdown, VERIFY the shutdown light is off and the drill engine can NOT be restarted.
RECONNECT instrument cable to above RPM sensor and DISCONNECT instrument cable from other RPM sensor. 


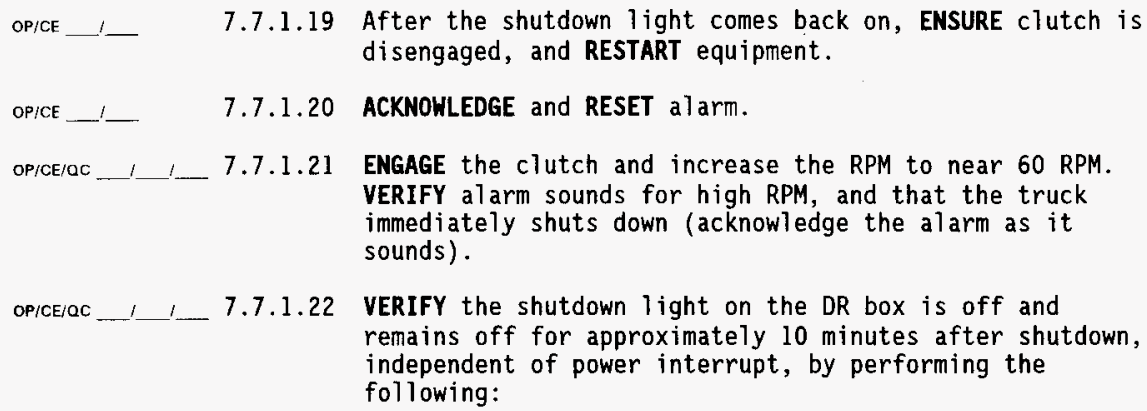

7.7.1.22 VERIFY the shutdown light on the DR box is off and remains off for approximately 10 minutes after shutdown, independent of power interrupt, by performing the following:

7.7.1.22.1 Approximately 3 minutes after shutdown, TURN OFF all breakers on the POWER DISTRIBUTION panel.

7.7.1.22.2 Approximately 5 minutes after shutdown, TURN ON all breakers on the POWER DISTRIBUTION panel, and VERIFY the shutdown light is off and the drill engine can NOT be restarted.

7.7.1.22.3 Approximately 12 minutes after shutdown (10 minutes plus power down time), VERIFY the shutdown light comes back on.
OPICE
7.7.1.23 RECONNECT instrument cable to above RPM sensor.
OPICE
7.7.1.24 ENSURE clutch is disengaged.
OPICE
7.7 .1 .25
PLACE PURGE GAS switch to OFF and CLOSE the PURGE GAS flow control.

\subsubsection{PURGE GAS FLOW ALARMS}

Adequate purge gas flow must be maintained to cool the rotating drill bit. A flow of at least $30 \mathrm{scfm}$ is required to keep the bit cool. If a flow rate of less than $32 \mathrm{scfm}$ is detected, the horn and strobe will go off as a warning to the operator. If a flow rate of less than $30 \mathrm{scfm}$ is detected an immediate shutdown will be initiated: the horn and strobe will go off and the drill rig will shut down.

OPICE

OP/CE

OP/CE
7.7.2.1 VERIFY the purge gas loop calibration is completed using the above set points (Ref. 6-ES-435).

7.7.2.2 ENSURE drill head and quill rod are positioned for testing.

ENSURE the nitrogen supply trailer, exhauster, and drill rig are operating, and any previous alarms are reset. 
$O P / C E / Q C$

7.7.2.14 SET PURGE GAS flow near $25 \mathrm{scfm}$. VERIFY that the HORN sounds, the STROBE flashes, the PURGE GAS LOW FLOW SHUTDOWN light flashes fast, and the truck immediately shuts down (acknowledge the alarm as it sounds).
$\mathrm{OP} / \mathrm{CE}$
7.7.2.15 DISENGAGE the clutch.
OP/CE
7.7 .2 .16
Within 10 minutes after shutdown, VERIFY the shutdown

Note: The below steps are to test the situation when one meter is not functioning and a low flow situation exists.
OPICE _ 7.7.2.17 After the shutdown light comes back on, RESTART the engine and ENGAGE the clutch.

OP/CE/QC

7.7 .2 .18
With the drill rotating and flow near 40 SCFM, TURN OFF the power to flow meter $\# 1$.

OP/CE/QC

7.7 .2 .19

DECREASE flow to between 30 and 32 SCFM and VERIFY low flow alarm sounds.

OP/CE/QC

7.7 .2 .20

INCREASE flow to near 40 SCFM, ACKNOWLEDGE and RESET al arm. 


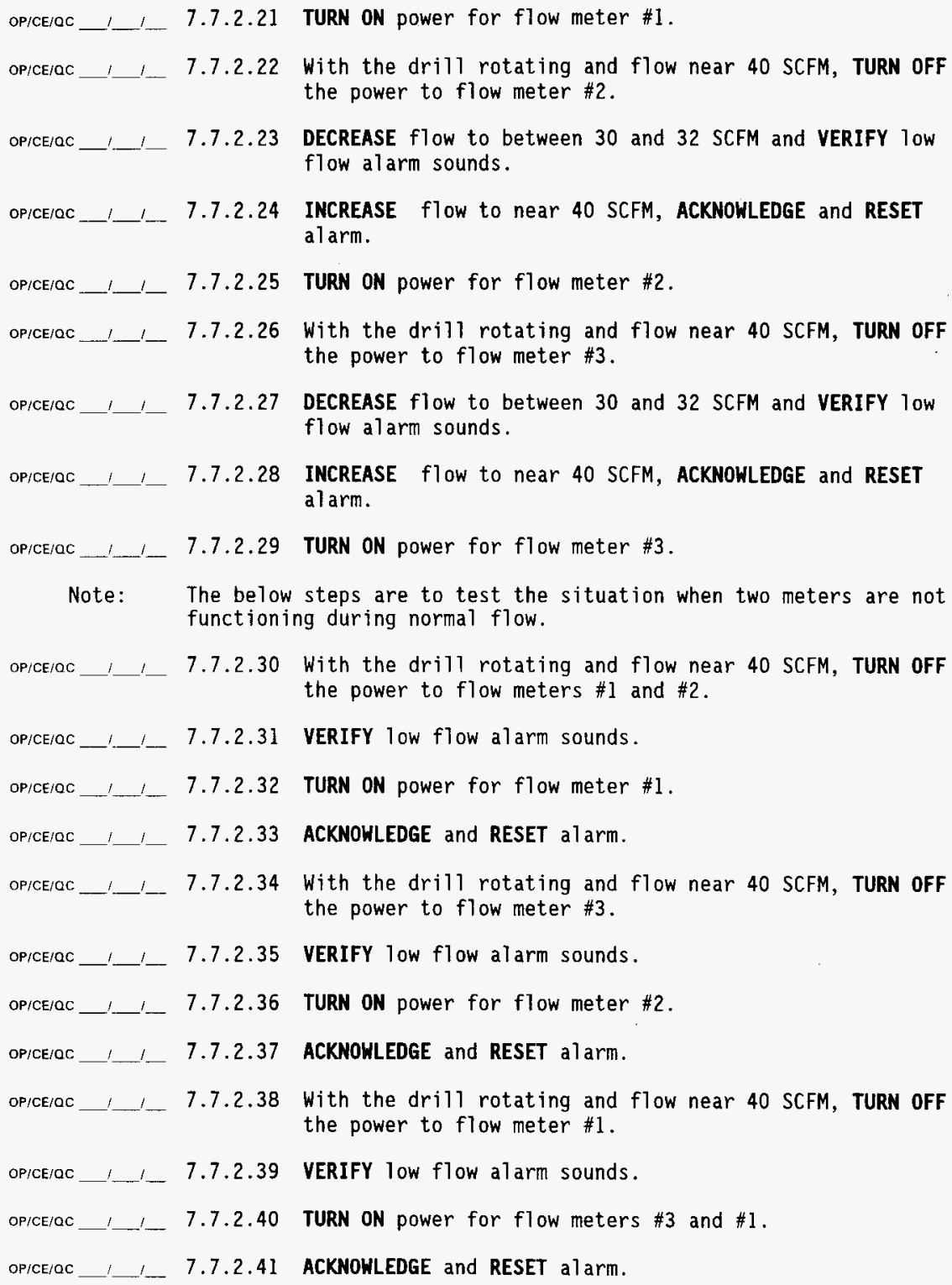


OPICE

7.7.2.42 DISENGAgE the clutch.

OP/CE

7.7 .2 .43

flow control.

\subsubsection{DOWN FORCE ALARM}

Drill bit downward force is a critical operating parameter. The down force limit is 750 pounds. If an excessive force of 700 pounds is detected, the horn and strobe will go off as a warning to the operator. If an excessive force of $\mathbf{7 5 0}$ pounds is detected, an immediate shutdown will be initiated: the horn and strobe will go off and the drill rig will shut down.
OPICE _-
7.7 .3 .1
VERIFY the down force loop calibration is completed using the above set points (Ref. 6-ES-433).

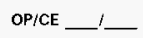
OP/CE
OPICE
OPICE
OPICE
OP/CE
OP/CE
OPICE
OP/CE
7.7 .3 .2
7.7 .3 .3
7.7 .3 .4
7.7 .3 .5
7.7 .3 .6
7.7 .3 .7
7.7 .3 .8
7.7 .3 .9
7.7 .3 .10
ENSUR
head.
ENSURE core barrel and bit are positioned for testing.
ENSURE the nitrogen supply trailer, exhauster, and dri11 rig are operating, and any previous alarms are reset.
ENSURE the flow control valves for Z-purge and riser sleeve purge are open and all alarms are reset.
PLACE the nitrogen MODE switch to the DRILL position and the PURGE GAS switch to ON.
SET PURGE GAS flow to near $40 \mathrm{scfm}$.
VERIFY that the chuck is CLOSED.
PLACE the transmission in gear, ENGAGE the clutch, and ENSURE the drill is rotating at 10 to 45 RPM.

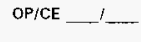
OP/CE
7.7 .3 .11
OP/CE/OC
7.7 .3 .12
ADJUST the ram hydraulic control valves, as necessary throughout the remainder of this test, to maintain a penetration rate greater than 0.75 inches per minute.
LOWER the rams until the bit contacts the drilling surface.
MONITOR the downward force. OPEN the DOWN ram hydraulic valve to increase the force to between 700 and 750 pounds. VERIFY that the HORN sounds, the STROBE flashes, and the DOWN FORCE HIGH light flashes fast.
OP/CE 7.7 .3 .13
PRESS the ALARM ACKNOWLEDGE button. VERIFY that the DOWN FORCE HIGH light stops blinking and remains lit. 


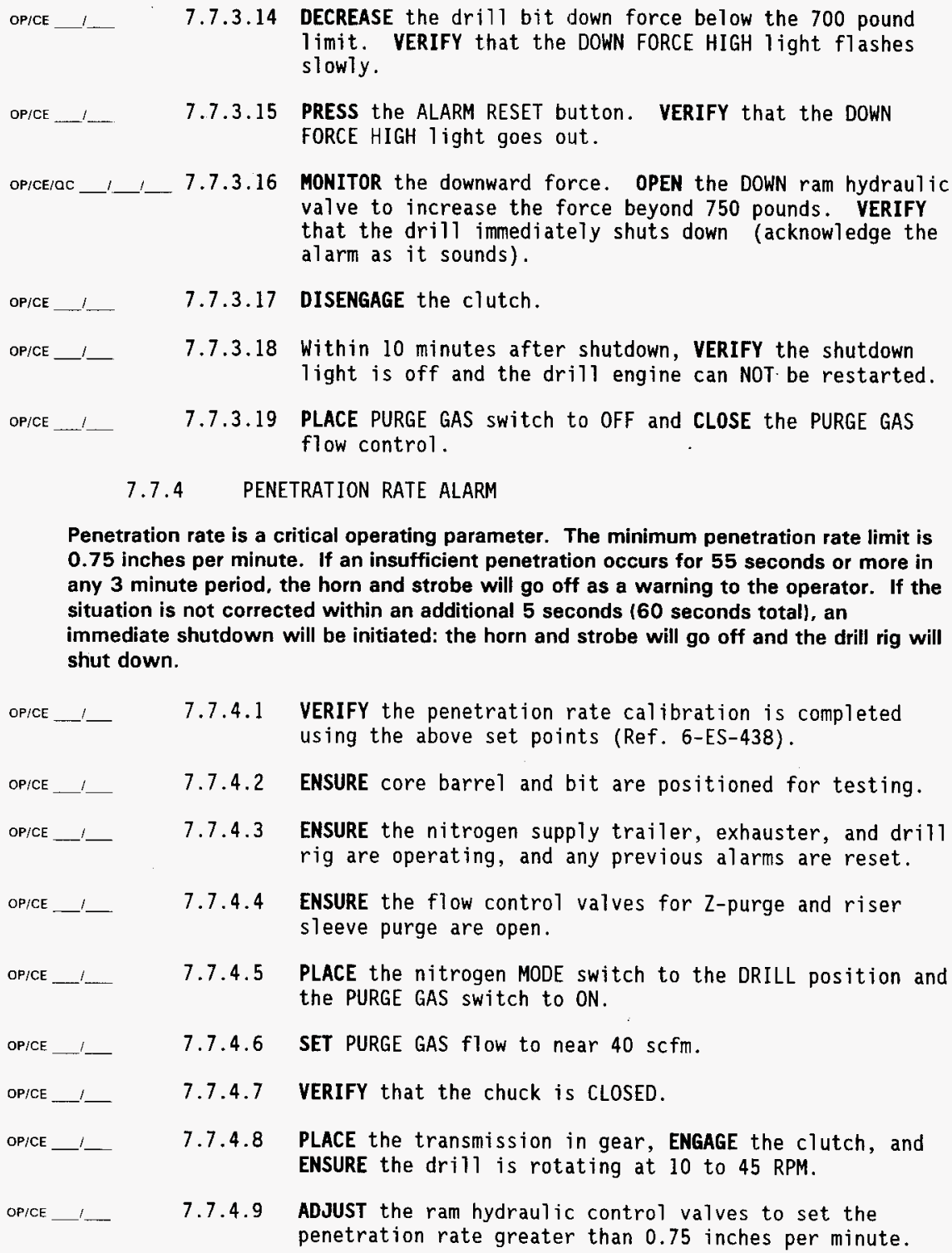

Penetration rate is a critical operating parameter. The minimum penetration rate limit is 0.75 inches per minute. If an insufficient penetration occurs for 55 seconds or more in any 3 minute period, the horn and strobe will go off as a warning to the operator. If the situation is not corrected within an additional 5 seconds (60 seconds total), an immediate shutdown will be initiated: the horn and strobe will go off and the drill rig will shut down. 
OP/CE/QC

7.7.4.10 MONITOR the penetration rate. ADJUST the DOWN ram hydraulic valve to reduce the penetration rate to below $0.75 \mathrm{in} / \mathrm{min}$ for at least 55 seconds, but less than 60 seconds. VERIFY that the HORN sounds, the STROBE flashes, and the penetration rate light flashes fast.

$\mathrm{OP} / \mathrm{CE}$

OP/CE

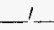

P/CE

$O P / C E / Q C$

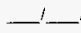

7.7 .4 .14

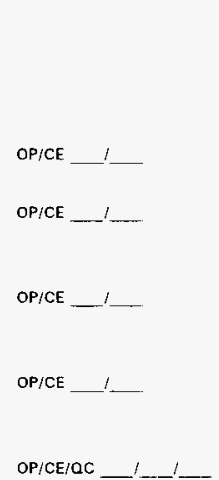

7.7 .4 .13

7.7 .4 .11

PRESS the ALARM ACKNOWLEDGE button. VERIFY that the Penetration rate light stops blinking and remains lit.

7.7.4.12 INCREASE the dri11 bit penetration rate above the 0.75 in/min limit. VERIFY that the Penetration rate light flashes slowly.

PRESS the ALARM RESET button. VERIFY that the Penetration rate light goes out.

MONITOR the penetration rate. ADJUST the DOWN ram hydraulic valve to reduce the penetration rate to below $0.75 \mathrm{in} / \mathrm{min}$ for a total of at least 60 seconds. VERIFY the drill immediately shuts down (for remaining tests acknowledge the penetration rate alarm as it sounds).

7.7.4.15 DISENGAGE the clutch.

7.7.4.16 Within 10 minutes after shutdown, VERIFY the shutdown light is off and the drill engine can NOT be restarted.

7.7.4.17 After the shutdown light comes back on, RESTART the engine and ENGAGE the clutch.

7.7.4.18 ADJUST the ram hydraulic control valves to set the penetration rate greater than 0.75 inches per minute.

7.7.4.19 MONITOR the penetration rate and perform the following:

7.7.4.19.1 ADJUST the DOWN ram hydraulic valve to reduce the penetration rate to below $0.75 \mathrm{in} / \mathrm{min}$ for approximately 30 seconds.

7.7.4.19.2 ADJUST the DOWN ram hydraulic valve to increase the penetration rate to above $0.75 \mathrm{in} / \mathrm{min}$ for approximately 100 seconds.

7.7.4.19.3 ADJUST the DOWN ram hydraulic valve to reduce the penetration rate to below $0.75 \mathrm{in} / \mathrm{min}$ for approximately 30 seconds (total of 60 second low penetration time within 3 minutes). VERIFY the drill immediately shuts down.

$\mathrm{OP} / \mathrm{CE}$

7.7 .4 .20

DISENGAGE the clutch.

$\mathrm{OP} / \mathrm{CE}$

7.7 .4 .21

Within 10 minutes after shutdown, VERIFY the shutdown light is off and the drill engine can NOT be restarted. 
$\mathrm{OP} / \mathrm{CE}$

OP/CE

OP/CE/OC

OP/CE

OP/CE/QC

$\mathrm{OP} / \mathrm{CE}$

7.7 .4 .27
After the shutdown light comes back on, RESTART the engine and ENGAGE the clutch.

7.7.4.23 ADJUST the ram hydraulic control valves to set the penetration rate greater than 0.75 inches per minute.

7.7.4.24 MONITOR the penetration rate and perform the following:

7.7.4.24.1 ADJUST the DOWN ram hydraulic valve to reduce the penetration rate to below 0.75 in/min for approximately 30 seconds.

7.7.4.24.2 ADJUST the DOWN ram hydraulic valve to reduce the penetration rate to above $0.75 \mathrm{in} / \mathrm{min}$ for approximately 125 seconds.

7.7.4.24.3 ADJUST the DOWN ram hydraulic valve to reduce the penetration rate to below $0.75 \mathrm{in} / \mathrm{min}$ for approximately 30 seconds (total of 55 second 10 w penetration time within 3 minutes). VERIFY the drill does NOT shut down.

7.7.4.25 ADJUST the ram hydraulic control valves to set the penetration rate greater than 0.75 inches per minute and RESET any alarms.

7.7.4.26 MONITOR the penetration rate and perform the following:

7.7.4.26.1 ADJUST the DOWN ram hydraulic valve to reduce the penetration rate to below $0.75 \mathrm{in} / \mathrm{min}$ for approximately 30 seconds.

7.7.4.26.2 TURN OFF all breakers on the POWER DISTRIBUTION POWER panel, WAIT approximately 30 seconds, and TURN breakers back ON.

7.7.4.26.3 DISENGAGE the clutch, and RESTART the engine.

7.7.4.26.4 ENGAGE the clutch, and ADJUST the DOWN ram hydraulic valve to maintain the penetration rate below $0.75 \mathrm{in} / \mathrm{min}$ for approximately 30 seconds (total of 60 second low penetration time within 3 minutes). VERIFY the drill immediately shuts down.

PLACE PURGE GAS switch to OFF and CLOSE the PURGE GAS flow control. 


\subsubsection{RISER SLEEVE PURGE ALARMS}

Adequate purge flow must be maintained to the riser sleeve. A differential pressure of at least $\mathbf{4 0}$ psi is required to ensure a minimum purge flow of $2 \mathrm{scfm}$. If insufficient differential pressure is detected an immediate shutdown will be initiated: the horn and strobe will go off and the drill rig will shut down.
OP/CE
7.7 .5 .1
VERIFY the riser sleeve purge calibration is completed using the above set point (Ref. 6-ES-431).
OP/CE _ _
7.7.5.2
ENSURE drill head and quill rod are positioned for testing.

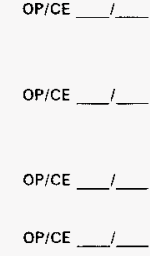
7.7 .5 .3
ENSURE the nitrogen supply trailer, exhauster, and drill rig are operating, and any previous alarms are reset.
7.7 .5 .4
PLACE the nitrogen MODE switch to the DRILL position and the PURGE GAS switch to ON.
7.7.5.5 SET PURGE GAS flow to near $40 \mathrm{scfm}$.
7.7 .5 .6
ADJUST the ram hydraulic control valves, as necessary throughout the remainder of this test, to maintain a penetration rate greater than 0.75 inches per minute.

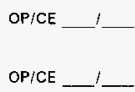
7.7.5.7 VERIFY that the chuck is CLOSED.
7.7 .5 .8
PLACE the transmission in gear, ENGAGE the clutch, and ENSURE the drill is rotating at 10 to $45 \mathrm{RPM}$.
OP/CE/OC
7.7 .5 .9
CLOSE RISER SLEEVE PURGE GAS ball valve located at the rear of the core sample truck, below the rotating platform. VERIFY that the HORN sounds, the STROBE flashes, the RISER SLEEVE LOW DP 1ight flashes fast, and the truck immediately shuts down (acknowledge the alarm as it sounds).
$\mathrm{OP} / \mathrm{CE}$
$\mathrm{OP} / \mathrm{CE}$
$\mathrm{OP} / \mathrm{CE}$
7.7 .5 .10
DISENGAGE the clutch.
7.7.5.11 Within 10 minutes after shutdown, VERIFY the shutdown light is off and the drill engine can NOT be restarted.
7.7.5.12 PLACE PURGE GAS switch to OFF and CLOSE the PURGE GAS flow control. 


\subsection{SYSTEM START UP / POWER LOADING TEST}

The purpose of the following test is to verify that all RMCS equipment can operate at the same time without causing circuit breakers to trip or other equipment problems. Voltage and current measurements are recorded for information only, and do not have quantitative acceptance criteria associated with them.
$O P / C E$
7.8 .1
START the diesel generator.
OP/CE
7.8 .2
START the Breathing Air Compressor (operate the compressor so that the pump motor cycles frequently, i.e. vent the tank).
$\mathrm{OP} / \mathrm{CE}$
7.8 .3
$\mathrm{OP} / \mathrm{CE}$ 7.8 .4
$\mathrm{OP} / \mathrm{CE}$ 7.8 .5
$O P / C E$ 7.8 .6

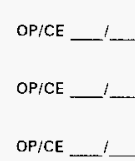
7.8 .7 7.8 .8 7.8 .9
OP/CE 7.8 .10
OP/CE 7.8 .11
OPICE 7.8. 12
START the air compressor on the sample truck (operate the compressor so the pump motor cycles frequently, i.e. vent the tank).
START the exhauster and FGD Interlock using procedure steps listed in section 6.2. Do not perform instrument start up calibrations or wait two hours for unit to stabilize. (Exhauster heater should cycle frequently.)
TURN ON the water heater on the support truck. (The heater should be heating throughout this test. If necessary, remove the heat blankets from the exterior of the water drum.)
TURN ON the water pump on the nitrogen trailer. (Power should be supplied to the vaporizer from the large generator not the one attached to the nitrogen trailer).
TURN ON flood lights on the service trailer.
TURN ON the 480 volt space heater.
TURN ON the power to all breakers on the sample truck console.
START the drill engine on the sample truck.
TURN ON the air conditioner in the service trailer, and allow to run for approximately 30 minutes.
TURN ON the $X$-Ray Imager, and operate to produce one image. 
OP/CE

7.8.13 During equipment operation, MEASURE and RECORD current and voltage readings for RMCS components in the table below (blank lines are provided for additional measurements per engineering direction).

\begin{tabular}{|c|c|c|}
\hline COMPONENT & Current, amps & Voltage, VAC \\
\hline \multicolumn{3}{|c|}{ For Record Only } \\
\hline \multicolumn{3}{|c|}{ Liquid Nitrogen Support Trailer } \\
\hline \multicolumn{3}{|c|}{ Service Trailer } \\
\hline \multicolumn{3}{|c|}{ Breathing Air Compressor } \\
\hline \multicolumn{3}{|c|}{ Electrical Distribution Trailer (EPDT) } \\
\hline \multicolumn{3}{|c|}{ Core Sample Truck } \\
\hline \multicolumn{3}{|c|}{ CST air compressor } \\
\hline \multicolumn{3}{|c|}{ Support Truck (water heater) } \\
\hline \multicolumn{3}{|c|}{ FGD Interlock Power Distribution Skid } \\
\hline \multicolumn{3}{|c|}{480 volt Space Heater } \\
\hline \multicolumn{3}{|c|}{$\mathrm{XRI}$} \\
\hline & & \\
\hline & & \\
\hline & & \\
\hline & & \\
\hline & & \\
\hline & & \\
\hline & & \\
\hline & & \\
\hline & & \\
\hline & & \\
\hline
\end{tabular}




\subsection{EXHAUSTER SHUTDOWN TESTS}

Note: The exhauster and FGD interlock are tested separately prior to integration with the balance of the RMCS system. These tests are listed in section 6.3 as test start prerequisites.

OPICE _ - 7.9.1 PERFORM exhauster start up per procedure steps in the exhauster procedure listed in 6.2 .

OPICE _ 1 7.9.2 ENSURE drill head and quill rod are positioned for testing.

OPICE _ 7.9.3 ENSURE riser equipment is connected to rock slinger pit modification and all ducting and flex hoses on the pit modification are secured.

OPICE _ 7.9.4 ENSURE the Exhauster Interlock 0verride switch on the core sample truck is in INTERLOCK position.

OP/CE

ENSURE the nitrogen supply trailer and drill rig are operating, and any previous alarms are reset.

7.9.6 COMPLETE the steps below to test the EXHAUSTER SHUTDOWN ALARM on the sample truck due to an exhauster shutdown:

The exhauster is tied to the truck via an interlock cable. The exhauster interlock is intended to prevent the sample truck from operating in the event the exhauster fails. If an exhauster shutdown is detected an immediate drill rig shutdown will be initiated: the horn and strobe will go off and the drill rig will shut down.
OPICE
7.9.6.1
PLACE the nitrogen MODE switch to the DRILL position and the PURGE GAS switch to ON.
OP/CE
7.9.6.2
SET PURGE GAS flow to near 40 scfm.

\begin{abstract}
OP/C
\end{abstract}
OP/CE
$\mathrm{OP} / \mathrm{CE}$
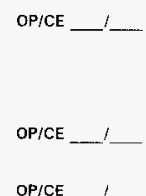
OP/CE
OP/CE
OP/CE
SHUT OFF the exhauster fan. VERIFY that the drill rig alarm HORN sounds, the STROBE flashes, the EXHAUSTER SHUTDOWN 1 ight flashes fast, and the truck immediately shuts down (acknowledge the alarm as it sounds).
7.9.6.4 VERIFY that the purge gas is automatically cut off when the truck shuts down.
7.9.6.5 Within 10 minutes after shutdown, VERIFY the drill rig shutdown light is off and the drill engine can NOT be restarted.
7.9.6.6 PLACE PURGE GAS switch to OFF.
7.9.6.7 CLOSE the PURGE GAS flow control.
7.9.6.8 START exhauster fan and ACKNOWLEDGE exhauster alarms.
7.9.6.9 CLEAR the EXHAUSTER SHUTDOWN alarm by pressing RESET. 
7.9.7 COMPLETE the steps below to test the EXHAUSTER SHUTDOWN ALARM from a FGD Interlock shutdown command:

The interlock cable is also intended to prevent continued sampling operations during a gas release event. The FGD interlock controls exhauster and core sample truck shutdown using the interlock cable and relays located on the exhauster. If a high flammable gas concentration (FGC), or high rate of FGC rise, or high tank pressure rise is detected an immediate drill rig shutdown will be initiated: the horn and strobe will go off and the drill rig will shut down. If a low tank pressure is detected an immediate RMCS system shutdown will be initiated: the horn and strobe will go off and the drill rig AND exhauster will shut down.
OP/CE _-
7.9 .7 .1
After the drill rig shutdown light comes back on, RESTART the drill rig engine and RESET alarms.
OP/CE/QC 7.9 .7 .2
Using a known FGC sample bottle connected to the FGD interlock sample port, INITIATE a hydrogen a $1 \mathrm{arm}$ condition on the FGD Interlock. VERIFY the drill rig alarm HORN sounds, the STROBE flashes, the EXHAUSTER SHUTDOWN light flashes fast, and the sample truck immediately shuts down (acknowledge the EXHAUSTER SHUTDOWN alarm as it sounds).
$\mathrm{OP} / \mathrm{CE}$
$7 \cdot 9.7 .3$
VERIFY high hydrogen alarm indication on FGD interlock carts.
OP/CE _ _
OPICE

- 7.9 .7 .6
OP/CEIAC
7.9 .7 .4
7.9 .7 .5
VERIFY exhauster fan continues to operate.
Within 10 minutes after shutdown, VERIFY the drill rig shutdown light is off and the drill engine can NOT be restarted.
After the shutdown light comes back on, RESTART the drill rig engine and RESET all alarms.
7.9.7.7 Using a test line connected to the FGD interlock tank pressure port, INITIATE a low tank pressure alarm condition on the FGD Interlock. VERIFY the sample truck AND exhauster immediately shut down (acknowledge the EXHAUSTER SHUTDOWN alarm as it sounds).

$\mathrm{OP} / \mathrm{CE}+1.9 .7 .8$
$\mathrm{OP} / \mathrm{CE} \_-\quad 7.9 .7 .9$
VERIFY tank pressure alarm indication on FGD interlock carts.
Within 10 minutes after shutdown, VERIFY the dril1 rig shutdown light is off and the drill engine can NOT be restarted.

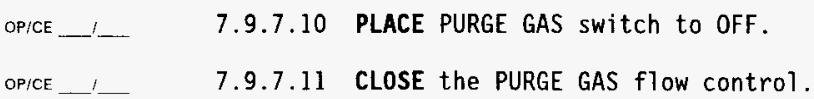
$\mathrm{OP} / \mathrm{CE}$
7.9 .7 .12
CLEAR
truck. 
7.9.8 COMPLETE the steps below to test the EXHAUSTER SHUTDOWN ALARM from a FGD Interlock signal loss:

The FGD Interlock is required to have redundant sensor/control capabilities and is designed to shut down the exhauster and sample truck when either cart looses signal input from the spool piece junction box or to the exhauster.
OP/CE
7.9.8.1
After the drill rig shutdown light comes back on, RESTART the drill rig engine and exhauster, and RESET al arms.
OP/CE/QC 7.9.8.2
DISCONNECT one spool piece junction box signal cable from one of the FGD Interlock carts. VERIFY the sample truck AND exhauster immediately shut down (acknowledge the EXHAUSTER SHUTDOWN alarm as it sounds).

\section{OPICE _ - 7.9.8.3 VERIFY the exhauster can NOT be restarted. \\ OP/CE the FGD Interlock cart and RESET alarms. \\ 7.10 DRILL STRING LOCKING COLLAR / RISER SLEEVE SPRAY WASHER}
7.9.8.4 RECONNECT the spool piece junction box signal cable to

\author{
Note: $\quad$ The riser sleeve installed for this OTP is a test unique version. All \\ interfaces on the riser sleeve, including nitrogen purge gas and wash \\ water connections, are identical to the operational riser sleeve. These \\ interfaces are tested in section 7.1. All other testing for the riser \\ sleeve is accomplished in the riser sleeve functional test. \\ OPICE__ \\ test document or work package number: \\ OP $/ \mathrm{CE} \quad$ P.10.2 POSITION drill string in foot clamp for locking collar test. \\ OP/CE__ 7.10.3 ATTACH test weights to drill string to provide a total load \\ of 210 pounds (minimum). \\ OP/CE__ 7.10.4 SECURE locking collar to drill string. \\ OP/CE_ $\quad 7.10 .5$ OPEN foot clamp and VERIFY locking collar does not release \\ drill string. \\ OPICE _ \\ from drill string.
}




\subsection{SAMPLING OPERABILITY TEST PROCEDURE}

The following items comprise the second phase of testing, as described in section 4.2. To reduce hazardous waste generated during testing, sampler ball valves will be closed during sampling (no sample will be taken), and samplers may be reused in testing. Testing is complete after operability of the flammable gas modifications is demonstrated by completing a full sampling cycle. More than one sampling cycle may be required if equipment maintenance or repairs significantly interrupt the continuity of sampling operations.

NOTE: $\quad$ The PRE-START INSPECTION (Appendix 3 Data Sheet) shall be completed EVERY time the RMCS truck is powered up.

\subsection{PREPARE TO SAMPLE}

OP/CE 8.1.1

ENSURE sample truck and support vehicles are positioned and ready for sampling in test pit.

OPICE _ 8.1.2 ENSURE cask stand and riser equipment are positioned and ready for sampling in test pit.

OP/CE__ 8.1.3 WHEN drill string calculations have been completed by engineering and verified by the PIC, OBTAIN drill rod lengths as specified by the Cog. Engineer.

OP/CE___ 8.1.4 ENSURE final truck leveling height conforms to FINAL QUILL ROD TO RISER FLANGE DISTANCE specified by Cog. Engineer.

OP/CE _ 8.1.5 INSTALL drill string, including rotary bit, core barrel, and closed-valve sampler, using applicable steps from section 5.1 of sampling procedure listed in 6.2 .

\subsection{PERFORM CORE SAMPLING}

OP/CE__ 8.2.1 DRILL a 19 inch segment using applicable steps from section 5.3 of the sampling procedure listed in 6.2 .

OP/CE__ 8.2.2 RETRIEVE pintle rod from drill string using applicable steps from section 5.4 of the sampling procedure listed in 6.2 . 


\subsection{RECOVER SPENT SAMPLER FROM DRILL STRING}

OP/CE _ 8.3.1 REMOVE the closed-valve sampler using applicable steps from section 5.5 of the sampling procedure listed in 6.2 .

OP/CE__ 8.3.2 LOAD sampler into cask using applicable steps from section 5.7 of the sampling procedure listed in 6.2 .

\subsection{INSERT EMPTY SAMPLER INTO DRILL STRING}

OP/CE__ 8.4.1 ENSURE a rebuitt or new closed-valve sampler is installed in sample cask.

OPICE _ - 8.4.2 INSTALL closed-valve sampler into drill string using applicable steps from section 5.8 of the sampling procedure 1 isted in 6.2 .

\subsection{RECOVER DRILL STRING AND SECURE EQUIPMENT}

Completion of operability testing does not require performance of this section. Equipment may be left in place for training or other program requirements. The following steps are provided as information to facilitate removal of RMCS equipment from the test site.

8.5.1 REMOVE the drill string using applicable steps from section 5.9 of the sampling procedure listed in 6.2 .

8.5.2 REMOVE RMCS equipment using applicable steps from section 5.12 through 5.15 of the setup and takedown procedure listed in 6.2 . 


\subsection{SIGNATURE LOG}

All persons initialing or signing within this procedure (including all data sheets and the test completion sign-off sheet) shall record their signature, initials, and printed name in the table below.

\begin{tabular}{|c|c|c|c|}
\hline Name (Print) & Company/Organization & Signature & Initia] \\
\hline \multicolumn{4}{|c|}{ For Record Only } \\
\hline & & & \\
\hline & & & \\
\hline & & & \\
\hline & & & \\
\hline & & & \\
\hline & & & \\
\hline & & & \\
\hline & & & \\
\hline & & & \\
\hline & & & \\
\hline & & & \\
\hline & & & \\
\hline & & & \\
\hline & & & \\
\hline & & & \\
\hline & & & \\
\hline & & & \\
\hline & & & \\
\hline t & & & \\
\hline & & & \\
\hline & & & \\
\hline & & & \\
\hline & & & \\
\hline & & & \\
\hline & & & \\
\hline
\end{tabular}




\subsection{TEST COMPLETION SIGN-OFF}

All system acceptance and operability tests have been completed as delineated in this ATP/OTP. A11 exceptions have been documented and resolved as indicated on the Exception / Resolution Data Sheet $(s)$. The core sample truck and associated equipment can be operated in a safe manner and are accepted as meeting all test criteria required for initial RMCS operations in flammable gas tanks.

\begin{tabular}{|c|c|}
\hline Signature & Date \\
\hline Operations PIC & \\
\hline Truck Sampling Manager & \\
\hline Quality Assurance & \\
\hline Safety & \\
\hline Cognizant Engineer & \\
\hline CFE Engineering Manager & \\
\hline Design Authority & \\
\hline Operations Test Director & \\
\hline
\end{tabular}


WHC-SD-WM-0TP-212 Rev. 0

\section{Exception / Resolution Data Sheet}

Note: This sheet is an example and may be replaced with a similar sheet containing the required information.

\begin{tabular}{|c|c|c|c|c|}
\hline $\begin{array}{l}\text { Except ion } \\
\text { Number }\end{array}$ & $\begin{array}{l}\text { Step } \\
\text { MLmber (s) }\end{array}$ & DESCRIPTION OF PROBLEM & RESOLUTION TO PROBLEM & $\begin{array}{l}\text { APPROVAL } \\
\text { INITIALS }\end{array}$ \\
\hline & & & & \\
\hline & & & & \\
\hline & & & & \\
\hline & & & & \\
\hline & & & & \\
\hline & & & & \\
\hline & & & & \\
\hline & & & & \\
\hline & & & & \\
\hline & & & & \\
\hline & & & & \\
\hline & & & & \\
\hline & & & & \\
\hline & & & ? & \\
\hline & & & & \\
\hline & & & & \\
\hline & & & & \\
\hline & & & & \\
\hline & & & & \\
\hline & & & & \\
\hline & & & & \\
\hline & & & & \\
\hline & & & & \\
\hline & & & & \\
\hline & & & & \\
\hline
\end{tabular}




\section{Test Log Comment Sheet}

For Record Only. This sheet is an example and may be replaced hith a similar sheet containing the required information.

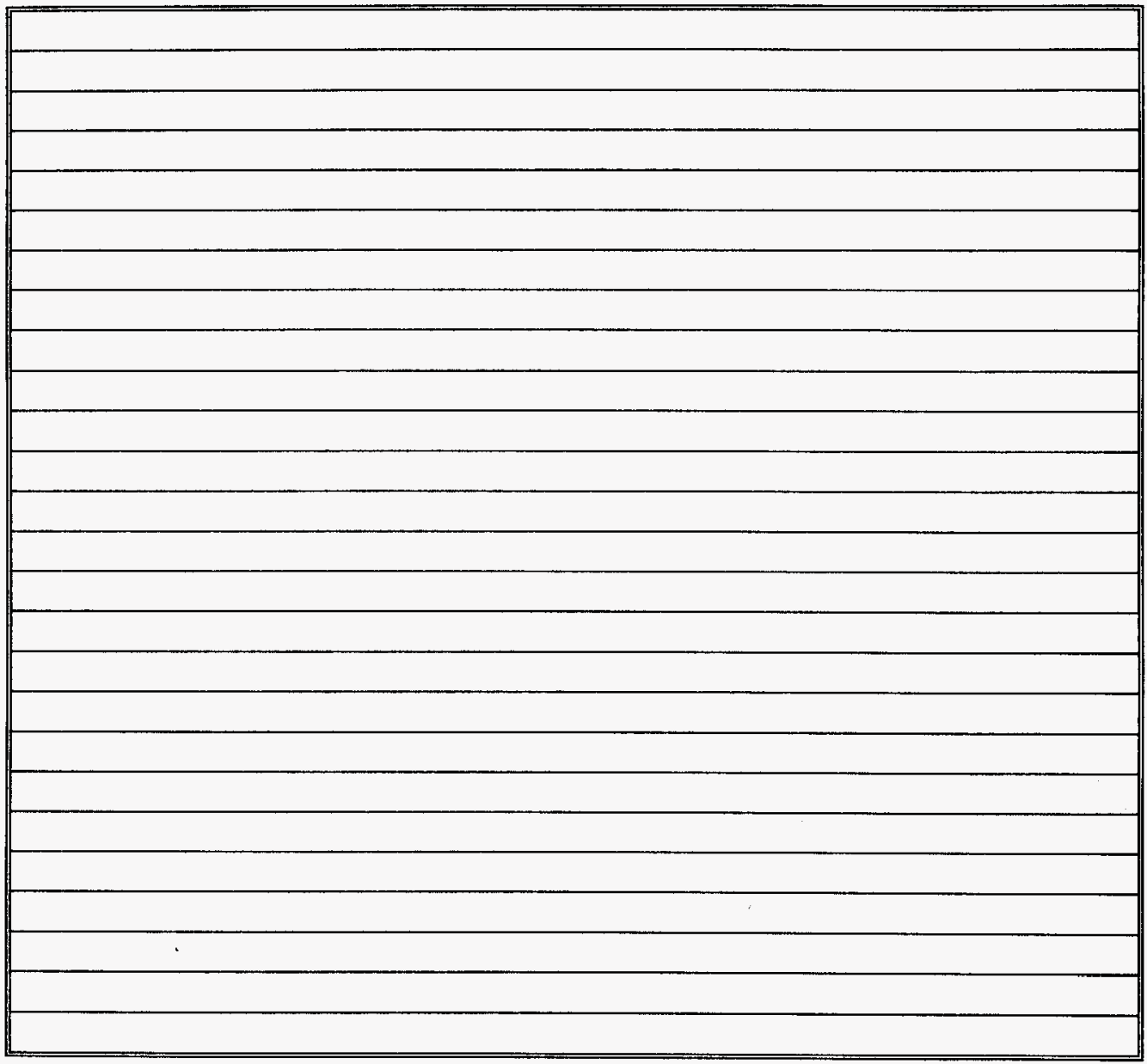




\section{Test Sample Data Sheet}

For Record Only. This sheet is an example and may be replaced hith a similar sheet containing the required information.

\begin{tabular}{|c|c|c|c|c|c|}
\hline 1 & SEGLENT NO. & SEG \# & CASK NO & SEG \# & CASK NO \\
\hline \multirow[t]{2}{*}{2} & SAMPLER NO,,$/ O-R I N G$ OR CHEYRON & SAMPLE \# & $\begin{array}{l}\text { SEAL O-RING } \\
\text { CHEV }\end{array}$ & SAMPLE \# & $\begin{array}{l}\text { SEAL O-RIHG } \\
\text { CHEV }\end{array}$ \\
\hline & SAMPLE NO. & & & & \\
\hline 3 & WASTE EXPECTED (SALT, SLUDGE OR 1 IOUID) & & & & \\
\hline 4 & COPY FROM LINE 16 OF PREVIOUS SEGMENT & ELEC & MECH & ELEC & MECH \\
\hline 5 & $\begin{array}{l}\text { RLU READING AT JOP "ZERO" (before lowering } \\
\text { Sampler) }\end{array}$ & ELEC & MECH & ELEC & MECH \\
\hline 6 & $\begin{array}{l}\text { RLU READ ING AT BOTTCW (when lowering } \\
\text { sampler) }\end{array}$ & ELEC & MECH & ELEC & MECH \\
\hline 7 & GPL COUNTER AT "ZERO" & \multicolumn{2}{|l|}{ REV } & \multicolumn{2}{|l|}{ REV } \\
\hline 8 & $\begin{array}{l}\text { GPL COUNTER AT BOTTOW (0.9 more for } 19 \mathrm{H} \\
\text { stroke) }\end{array}$ & \multicolumn{2}{|l|}{ REV } & \multicolumn{2}{|l|}{ REV } \\
\hline 9 & PG PRESSURE & PSIG & SCFM & PS1G & SCFM \\
\hline 10 & DOW FORCE (LBS) & \multicolumn{2}{|l|}{ LBS } & \multicolumn{2}{|l|}{ LBS } \\
\hline 11 & PIC IHITIALS & PIC & NPO & PIC & NPO \\
\hline 12 & \begin{tabular}{l|l|} 
PENETRATION & $\begin{array}{l}\text { ROTATION } \\
\text { RATE (IPN) }\end{array}$ \\
SPEED (RPM)
\end{tabular} & IPM & RPM & IPM & RPM \\
\hline \multirow{2}{*}{13} & \multirow[t]{2}{*}{ GRAPPLE ACTIVITY } & TIME & DATE & IIME & DATE \\
\hline & & SHEAR & DROP & SHEAR & DROP \\
\hline 14 & $\begin{array}{l}\text { EXPECTED RLU AT BOTTOM (iten } 6+1.581 \text { if } \\
\text { 19* rod added) }\end{array}$ & ELEC & МЕСН & ELEC & MECH \\
\hline 15 & RLU RENDING AT TOP "ZERO" (before unseating) & ELEC & MECH & ELEC & MECK \\
\hline 16 & RLU READING AT BOTIOM (when unseating) & ELEC & MECH & ELEC & MECH \\
\hline \multirow[t]{2}{*}{17} & \multirow[t]{2}{*}{ HAX FORCE TO UWSEAT SAMPLER } & \multicolumn{2}{|l|}{ FORCE } & \multicolumn{2}{|l|}{ FORCE } \\
\hline & & TIME & DATE & TIME & DATE \\
\hline 18 & RAD DOSE RATE THROUGH DS & & & & \\
\hline 19 & UATER USED? & & & & \\
\hline 20 & DS MITROGEN & PSIG & SCFM & PSIG & SCFM \\
\hline
\end{tabular}




\section{Pre-start Inspection Data Sheet}

For Record Only. This sheet is an example and mar be replaced hith a similar sheet containing the required imformation.

\begin{tabular}{|l|l|l|l|l|l|l||}
\hline $\begin{array}{l}\text { CONDITIONS SHALL BE VERIFIED AT THE } \\
\text { BEGINNING OF EACH SHIFT. } \\
\text { (CHECK EACH CONDITION WHEN VERIFIED.) }\end{array}$ INITIAL: & & & & & \\
\hline & & & & & \\
\hline SR AND QR ARE POSITIONED FOR SAFE OPERATION & & & & & \\
\hline DRILL HEAD RAM CONTROL VALVES CLOSED & & & & & \\
\hline 4 WAY VALVE IN HEAD OR FLOAT POSITION & & & & & \\
\hline JACK HOSES DISCONNECTED & & & & & \\
\hline INSPECT ELECTRICAL CORDS FOR DAMAGE & & & & & \\
\hline INSPECT HYDRAULIC LINES \& FITTINGS FOR LEAKAGE \\
AND/OR DAMAGE
\end{tabular}

